\title{
Does the Addition of Cellulosic Micro/nanofibrils Improve the Properties of Hydroxypropyl Methylcellulose Films?
}

Adriano Reis Prazeres Mascarenhas ( $\nabla$ adriano.mascarenhas@unir.br )

Federal University of Rondônia: Universidade Federal de Rondonia https://orcid.org/0000-0002-75543590

\section{Mário Vanoli Scatolino}

State University of Amapa

Allan de Amorim dos Santos

Universidade Federal de Lavras

\section{Laís Bruno Norcino}

Federal University of Lavras: Universidade Federal de Lavras

Paulo Junio Duarte

Federal University of Lavras: Universidade Federal de Lavras

Rafael Rodolfo de Melo

UFERSA: Universidade Federal Rural do Semi-Arido

Matheus Cordazzo Dias

Federal University of Lavras: Universidade Federal de Lavras

Caik Elisio Tonelli de Faria

Federal University of Lavras: Universidade Federal de Lavras

Maressa Carvalho Mendonça

Federal University of Lavras: Universidade Federal de Lavras

Gustavo Henrique Denzin Tonoli

Federal University of Lavras: Universidade Federal de Lavras

\section{Research Article}

Keywords: Blends, Biopolymers, Cellulose, Nanotechnology, Nanocomposites

Posted Date: December 29th, 2021

DOI: https://doi.org/10.21203/rs.3.rs-1175984/v1

License: (c) (1) This work is licensed under a Creative Commons Attribution 4.0 International License.

Read Full License 



\section{A.R.P. Mascarenhas*}

ORCID: 0000-0002-7554-3590

E-mail: adriano.mascarenhas@unir.br

M.V. Scatolino

ORCID: 0000-0002-0412-994X

E-mail:marioufla@posgrad.ufla.br

\section{A.A. Santos}

ORCID: 0000-0003-1600-7824

E-mail: allandeamorim@hotmail.com

\section{L.B. Norcino}

ORCID: 0000-0002-6670-4479

E-mail: lais.norcino@estudante.ufla.br

\section{P.J. Duarte}

ORCID: 0000-0002-7319-3101

E-mail: pauloduarte.floresta@gmail.com

\section{R.R. Melo}

ORCID: 0000-0001-6846-2496

E-mail: rafael.melo@ufersa.edu.br

\section{M.C. Dias}

ORCID: 0000-0002-8154-2543

E-mail: matheus.cordasso@gmail.com

\section{C.E.T. Faria}

ORCID: 0000-0002-0138-6801

E-mail: caiktonelli@gmail.com

\section{M.C. Mendonça \\ ORCID: 0000-0001-7532-7794}

E-mail: maressacmendonca@gmail.com

\section{G.H.D. Tonoli}

ORCID: 0000-0002-6502-8974

E-mail: gustavotonoli@ufla.br

\section{AFFILIATIONS}

*Corresponding author

\section{films?}

${ }^{1}$ Department of Forest Engineering, Federal University of Rondônia (UNIR), 76940-000, Rolim de Moura, RO, Brazil.

${ }^{2}$ Department of Production Engineering, State University of Amapá (UEAP), 68900-070, Macapá, AP, Brazil.

${ }^{3}$ Department of Forest Science, Federal University of Lavras (UFLA), C.P. 3037, 37200-900, Lavras, MG, Brazil.

${ }^{4}$ Agricultural Sciences Center, Federal University of the Semiarid(UFERSA), 59625-900, Mossoró, RN, Brazil. 


\section{Abstract}

Damages to ecosystems, due to the consumption of petroleum-based materials, can be mitigated with the use of biopolymers such as cellulose derivatives. The objective was to evaluate the influence of different proportions of cellulose micro/nanofibrils (MFC/NFC) on the properties of hydroxypropyl methyl cellulose (HPMC) films. Films were prepared using proportions of 0, 25, 50, 75 and 100\% (w/w) of MFC/NFC of Pinus sp. in relation to HPMC. The physical, barrier, surface, optical, morphological and mechanical properties were evaluated. Data were analyzed with descriptive statistics, linear regression, principal component analysis and Pearson correlation. Solids content, basis weight and density values increased with higher MFC/NFC amount, while thickness and porosity were reduced. SEM images showed that films with more than 50\% MFC/NFC had a more granular surface resulting in reduction of transparency from 80 to $65 \%$. The water vapor penetration did not differ between films and the degradation in water was reduced from 40 to $5 \%$ as MFC/NFC was added. There were no differences for contact angle and wettability, but all films showed high resistance to fat penetration. Films with MFC/NFC contents between 75 and 100\% showed higher values for tensile strength (50 to $65 \mathrm{MPa}$ ) and Young's modulus (6 to $10 \mathrm{MPa}$ ) and lower elongation at break (1 to $2 \%$ ). The experimental results indicated that films with MFC/NFC contents above $50 \%$ have potential to be used as packaging material.

Keywords: Blends. Biopolymers. Cellulose. Nanotechnology. Nanocomposites.

\section{Introduction}

The consumption of non-renewable polymers has raised concerns about environmental damage to ecosystems. It is estimated that in 2020 the world production of plastics exceeded 368 million metric tons (Mt) with the possibility of be doubled in the next 20 years (Blasiak et al. 2021; Leal Filho et al. 2021; Perosa et al. 2021; Walker 2021). Other research report that at least 30\% of plastics produced are single-use, especially when intended for packaging production (Okan et al. 2018; Lavers et al. 2019; Chen et al. 2021a). Consequently, numerous environmental problems are caused, affecting the dynamics of terrestrial and aquatic ecosystems, increasing carbon emissions to the atmosphere and causing diseases on digestive, respiratory and circulatory humans systems (Cox et al. 2020; Groh et al. 2019; Amato-Lorenço et al. 2020; Shen et al. 2020). Thus, biopolymers become an alternative to replace petroleum-derived materials, reducing the mentioned problems.

Among the most studied biopolymers for this purpose, cellulose stands out due to its availability, being renewable and widely used in the food, health, civil construction, cosmetics and composites production sectors. (Foster et al. 2018; Adbelhamid and Mathew 2022). Cellulose versatility allows its modification for different uses, expanding its potential in the development of new products, such as hydroxypropyl methylcellulose (HPMC) and cellulosic micro/nanofibrils (MFC/NFC). HPMC is one of the most used cellulose ethers in the food industry, as emulsifier, protective colloid, stabilizer, suspending agent, and film former (Tudoroiu et al. 2021; Tundisi et al. 2021). Films obtained from HPMC are resistant to oils and grease, flexible, transparent, odorless and tasteless, but tending to have moderate mechanical resistance (Bilbao-Sainz 2011; Larsson et al. 2017).

The MFC/NFC is a material with high specific surface and great capacity to generate intermolecular hydrogen bonds. The high MFC/NFC aspect ratio favors the formation of a rigid and homogeneous network, with low porosity (Viana et al. 2017; Li et al. 2021; Morais et al. 2021). These characteristics are interesting for MFC/NFC applications as composites reinforcement aiming the development of new materials such as biodegradable films for packaging (González et al. 2012). 
In this context, the use of cellulosic nanofibrils as bionanocomposites reinforcement has been object of frequent study. Krishnadev et al. (2021) studied HPMC films reinforced with $1 \%$ (m/v) of MFC/NFC and obtained increase in order of 30\% in tensile strength and Young's modulus. However, the transparency was reduced from 74 to $32 \%$ and water vapor permeability was reduced around $40 \%$. Similarly, Hassan et al. (2018) added cellulosic nanofibrils contents ranging from 10 to $75 \%$ in HPMC matrices, achieving a linear increase on films mechanical strength. Additionally, the mentioned authors observed a reduction in water vapor permeability of around $30 \%$.

These results show that MFC/NFC is a class of material that may improve the barrier, mechanical and thermal properties of bionanocomposites compared to conventional composites and materials produced from pure polymers, making them a promising option to be used as biopolymer-based packaging materials (Lindström and Österberg 2020; Hu et al. 2021; Naidu and John 2021). The different combinations and proportions between HPMC and MFC/NFC, as well as the variation of experimental conditions among the research, makes it difficult to standardize the results (Khalil et al. 2018; Li et al. 2018; Ghadermazi et al. 2019).

The points abovementioned show the importance of studying the proportions between these materials in order to obtain greater predictability of results to support products development with viable performance for applications in packaging and composites. In this context, the objective of the work was to evaluate the influence of adding different proportions of MFC/NFC in HPMC films, on their physical, mechanical, morphological, optical, and barrier properties.

\section{Material and methods \\ Obtainment of materials}

Hydroxypropyl methylcellulose - HPMC (Celotex K60) produced by Aditex Indústria e Comércio de Produtos Químicos LTDA (São Paulo, Brazil) was used as films matrix. MFC/NFC from commercial kraft bleached pulp of Pinus sp. (Paraná, Brazil) were used as matrix reinforcement. To facilitate the fibrillation, the pulps were oxidized by the action of N-oxyl-2,2,6,6-tetramethylpiperidine (TEMPO) provided by Sigma-Aldrich Products (Missouri, USA).

\section{Production of the MFC/NFC}

The cellulosic pulp was pretreated by action of TEMPO-mediated oxidation, according to the methodology described in Saito et al. (2007). A suspension of $60 \mathrm{~g}$ of cellulosic pulp in $3 \mathrm{~L}$ of deionized water was prepared. The reaction with TEMPO was kept for $3 \mathrm{~h}$ at room temperature under mechanical stirring of 600 $\mathrm{rpm}$. The suspension had the $\mathrm{pH}$ adjusted to 7 by addition of $0.5 \mathrm{~mol} / \mathrm{L}$ of $\mathrm{HCl}$ and it was carefully washed with deionized water after the treatment.

Suspension fibrillation was performed with 5 passes through the grinder (Super Mass Colloider Masuko Sangyo MKCA6-2). The distance between the equipment stone discs was $10 \mu \mathrm{m}$ with rotation speed of $1500 \mathrm{rpm}$ (Dias et al. 2019). After the fibrillation process, the suspension concentration was adjusted to $1 \%(\mathrm{~m} / \mathrm{m})$ and an ultrasonic treatment was performed (60 MHz for $5 \mathrm{~min}$ ) to disperse the MFC/NFC.

\section{Preparation of the HPMC suspension}

The HPMC suspension was prepared by adapting the hot/cold technique described by Bilbao-Sainz (2011). HPMC (11.05 g) was mixed to $0.5 \mathrm{~L}$ of distilled water under mechanical stirring at $90{ }^{\circ} \mathrm{C}$ and $500 \mathrm{rpm}$ for 
30 min. Subsequently, the mixture was removed from heating and $0.5 \mathrm{~L}$ of distilled water $\left(25^{\circ} \mathrm{C}\right)$ was added, being the new suspension stirred for $20 \mathrm{~min}$ at $500 \mathrm{rpm}$. The final suspension was obtained in concentration of $1 \%$ (w/w).

\section{Preparation of the films}

Complementary proportions of $25 \% / 75 \%, 50 \% / 50 \%$ and $75 \% / 25 \%$ between MFC/NFC and HPMC were mixed, according to the dry mass of each filmogenic suspension. Pure films of HPMC and MFC/NFC were also produced. Each mixture was homogeneized by mechanical stirring for $30 \mathrm{~min}$ at $500 \mathrm{rpm}$. The films were prepared by solvent evaporation from the suspensions (casting), according to the methodology described in Prado et al. (2017). Four films of each composition were produced, with $40 \mathrm{~g}$ of each filmogenic suspension poured into acrylic plates with $14 \mathrm{~cm}$ of diameter. The plates were kept in environment with temperature of $25^{\circ} \mathrm{C}$ and $60 \%$ of relative humidity until total solvent evaporation.

\section{Morphology of the suspensions}

The morphology of MFC/NFC was evaluated by transmission eletronic microscopy, with a Zeiss EM109 microscope (Oberkochen, Germany) adjusted with accelerated voltage of $80 \mathrm{kV}$. Suspensions with a concentration of $0.001 \%(\mathrm{w} / \mathrm{w})$ of MFC/NFC were prepared and subjected to sonication (150 Hz for $2 \mathrm{~min}$ ). With a micropipette, $4 \mu \mathrm{L}$ of suspension were deposited in microgrids (400 mesh) with FORMVAR and dried at room temperature in a desiccator. After drying, $4 \mu \mathrm{L}$ of uranyl acetate solution $(2 \% \mathrm{w} / \mathrm{w})$ were added following the procedures described in Silva et al. (2020). Measurements of MFC/NFC diameter were performed for at least 200 individual structures in 27 images using the software ImageJ.

\section{Physical properties of the films}

The films were conditioned at temperature of $25{ }^{\circ} \mathrm{C}$ and relative humidity $65 \%$, following the recommendations the TAPPI T $402 \mathrm{sp}-21$ standard (TAPPI 2021). The thickness of the films was obtained using a flat tip digital micrometer Mitutoyo $(0.001 \mathrm{~mm})$, following the TAPPI T $411 \mathrm{om}-15$ standard (TAPPI 2015). The grammage was obtained in accordance with TAPPI T 410 om-08 (TAPPI 2013), weighing the films in analytical balance and determining their respective areas with digital caliper $(0.001 \mathrm{~mm})$. The grammage was calculated with the ratio mass/ area. The bulk density of the films was calculated by the ratio mass/thickness and the porosity of the films was calculated using equation 1, proposed by Desmaisons et al. (2017). To obtain these results, 5 samples per treatment were evaluated.

$$
\text { Porosity }(\%)=1-\left(\frac{d}{\rho_{c}}\right)
$$

Where: $d=$ density of the films $\left(\mathrm{g} / \mathrm{cm}^{3}\right), \rho_{\mathrm{c}}=$ density of the cellulose $\left(\cong 1,54 \mathrm{~g} / \mathrm{cm}^{3}\right)$.

\section{Morphology of the films}

The films were immersed in liquid nitrogen for instant freezing, fractured and fixed in sample holders (stubs) containing double-sided carbon adhesive tapes. Subsequently, the material was submitted to metallic coating in a gold evaporator (SCD 050) and taken to a scanning electron microscope (LEO EVO 40 XVP) for micrographs obtainment from the surface and cross-section of the films. 

Where: $\mathrm{WD}=$ degradation in water $(\%) ; \mathrm{Mi}=$ initial mass $(\mathrm{g})$ e $\mathrm{Mf}=$ final mass after drainage $(\mathrm{g})$.

\section{Transparency of the films}

The transparency of the films was obtained by measuring the percentage of transmittance in a UV/VIS SP 2000 spectrophotometer (Bel®) set at $600 \mathrm{~nm}$, according to the procedures described in Sothornvit et al. (2010) and ASTM D1746 (ASTM 2015). For each treatment, 4 samples with dimensions of $3 \times 2 \mathrm{~cm}$ were evaluated. Before the analysis, the thickness were measured with a flat tip micrometer Mitutoyo $(0.001 \mathrm{~mm})$. Transparency was calculated according to equation 2 .

$$
\text { Transparency }(\%)=\frac{(\log \mathrm{T})}{\mathrm{ft}}
$$

Where: $\mathrm{T}=$ transmittance in $600 \mathrm{~nm}(\%)$, and $\mathrm{ft}=$ film thickness $(\mathrm{mm})$.

\section{Water vapor permeability (WVP)}

Before analysis, the samples with $16 \mathrm{~mm}$ of diameter were kept in acclimatized room at temperature of $25{ }^{\circ} \mathrm{C}$ and relative humidity $65 \%$ for 3 days, in accordance with ASTM E96-16 (ASTM 2016). For each treatment, 10 samples were evaluated. The samples were placed in glass capsules partially filled with silica, which were placed in desiccators containing saturated $\mathrm{NaCl}$ solution $(360 \mathrm{~g} / \mathrm{L})$ at $25^{\circ} \mathrm{C}$, creating an atmosphere with $75 \%$ of relative humidity, according to ASTM E104-02 (ASTM 2012). The capsules with the films and silica were weighed in analytical balance for 8 days. The water vapor transmission rate and water vapor permeability were calculated by the equations 3 and 4 .

$$
\begin{gathered}
\text { WVTR }=\frac{M}{t \times \mathrm{A}} \times 100 \\
\mathrm{WVP}=\frac{(\mathrm{WVTR} \times \mathrm{Th})}{\left(\mathrm{p} \times \mathrm{H}_{o}-\mathrm{H}_{i}\right)} \times 100
\end{gathered}
$$

Where: $\mathrm{WVTR}=$ water vapor transmission rate $\left(\mathrm{g} / \mathrm{m}^{2}\right.$ day $)$; $\mathrm{WVP}=$ water vapor permeability $\left(\mathrm{g} \mathrm{mm} / \mathrm{kPa}^{-1}\right.$ day $\left.\mathrm{m}^{2}\right) ; \mathrm{M} / \mathrm{t}=$ angular coefficient from the graph obtained by the linear regression of the mass gain $(\mathrm{g})$ versus conditioning time (days); $\mathrm{A}=$ exposed area of the sample $\left(\mathrm{m}^{2}\right)$; $\mathrm{Th}=$ thickness of the samples $(\mathrm{mm}) ; \mathrm{p}=$ water vapor pressure $(\mathrm{kPa})$; and $\mathrm{H}_{\mathrm{o}}-\mathrm{H}_{\mathrm{i}}$ is the difference between the humidity outside and inside the glass capsules at $25^{\circ} \mathrm{C}$.

\section{Degradation in water of the films}

Degradation in water was evaluated by the average value of 4 samples $(20 \times 20 \mathrm{~mm})$ per treatment. The samples were dried in an oven at a temperature of $103 \pm 1{ }^{\circ} \mathrm{C}$ and, after cooling in a desiccator, they were weighed and immersed in a beaker with $100 \mathrm{~mL}$ of distilled water for $24 \mathrm{~h}$. After this time, ter samples were taken from the beaker and the excessive water was drained. The films were dried at $103 \pm 1{ }^{\circ} \mathrm{C}$ and weighed again in analytical balance $(0.001 \mathrm{~g})$. Degradation in water was calculated according to the equation 5 (Scatolino et al. 2017).

$$
\mathrm{WD}=\frac{(\mathrm{Mi}-\mathrm{Mf})}{\mathrm{Mi}} \times 100
$$




\section{Contact angle, wettability and grease resistance of the films}

The contact angle and wettability were evaluated according to the standard TAPPI T $458 \mathrm{~cm}-14$ (TAPPI 2014). The contact angle measurements of the sessile drop were performed using a goniometer (Krüss DSA30, Hamburg, Germany). The samples were fixed on a glass slide and placed on the base of the equipment's image acquisition system. Ten samples $(10 \times 100 \mathrm{~mm})$ were evaluated for each composition. The measurements were done by deposition of distilled water drops $(\cong 3.2 \mu \mathrm{L})$ on the upper and lower film faces and calculating the average contact angle between the drop and the film surface after $5 \mathrm{~s}$.

The wettability of the films was calculated by the average of the contact angles measured between 5 and $55 \mathrm{~s}$, according to the equation 6 .

$$
\mathrm{W}=\frac{(\mathrm{A}-\mathrm{a})}{55} \times 100
$$

Where: $\mathrm{W}=$ wettability $\left({ }^{\circ} / \mathrm{s}\right) ; \mathrm{A}=$ average of the contact angle after $5 \mathrm{~s}\left({ }^{\circ}\right)$ and $\mathrm{a}=$ average of the contact angle after $60 \mathrm{~s}\left({ }^{\circ}\right)$.

The grease resistance test was conducted according to TAPPI T $559 \mathrm{~cm}-12$ (TAPPI 2012). Ten samples (216 x $279 \mathrm{~mm})$ were evaluated for each composition. The solutions were classified from 1, less aggressive and composed only of oil, to 12, more aggressive and composed of toluene and n-heptane. A drop of oil solution was applied on the sample surface, being removed after $15 \mathrm{~s}$ of contact with the film. The films were classified with the highest solution score ( 1 to 12 ) that permeates the sample. This score was compared among the other compositions.

\section{Mechanical properties of the films}

Mechanical tests were performed according to ASTM D 882-18 (ASTM 2018), using a texturometer (Stable Micro Systems, TATX2i, England) equipped with a load cell with capacity of $500 \mathrm{~N}$. The tensile strength, Young's modulus and elongation at break in the tensile test, five specimens $(10 \mathrm{x} 100 \mathrm{~mm})$ of each treatment were evaluated. Before the test, the thickness of the samples were measured. The initial distance between the grips was $50 \mathrm{~mm}$ and the test was conducted at speed of $0.8 \mathrm{~mm} / \mathrm{s}$.

\section{Experimental design and statistical analysis}

The experiment was carried out in a completely randomized design. The results of physical, mechanical, surface and barrier tests were submitted to Shapiro-Wilk and Analysis of variance (ANOVA) (p < 0.01). In case of statistical differences among the averages, regression equations were adjusted in function of the different MFC/NFC contents $(0 \%, 25 \%, 50 \%, 75 \%$ and $100 \%)$ added to the HPMC films. Parameters with any influence of MFC/NFC contents were presented using descriptive statistics. All analyzes were performed by the software Sisvar 5.6 (Ferreira 2019).

Additionally, the Principal Component Analysis (PCA) was carried out aiming to agroup the treatments in "clusters" according to the variation of their characteristics. The analysis was proceeded with the maximum of eight principal components by the FactoMineR package in the software R (Le et al. 2008; R Core Team 2020). The existence of correlation between the properties of the films was verified by the Metan package, present in the mentioned software. Pearson correlation $(\mathrm{p}<0.01)$ was applied and analyzed using a correlogram. 


\section{Results and discussion}

\section{Morphology of the suspensions}

Measurements showed more than $70 \%$ of cellulosic micro/nanofibrils (MFC/NFC) with diameters below $30 \mathrm{~nm}$ (Fig. 1). The highest frequency (52.5\%) was observed for diameter class from 15 to $30 \mathrm{~nm}$, whereas the lowest frequency was observed for the class from 60 to $75 \mathrm{~nm}(2 \%)$. The general visual aspect regarding the individualization of the structures, and average of the MFC/NFC diameters, it is possible to say that the fibers treatment with TEMPO before the fibrillation was efficient in the cell wall deconstruction.

\section{[Insert Fig. 1]}

Fig. 1 Frequency of diametric distribution of MFC/NFC produced from cellulosic pulp of Pinus sp. subjected to TEMPO mediated oxidation

Similar results were reported in Lengowski et al. (2018), who found MFC/NFC diameters ranging between 12 to $26 \mathrm{~nm}$. from Pinus sp., after 10 passes through the fivrillator, without chemical pre-treatments. Chinga-Carrasco et al. (2011) produced MFC/NFC from Pinus sp., proceeding TEMPO oxidation in a high pressure homogenizer ( 3 to 5 passes), and observed the most of diameters ranging from 10 to $20 \mathrm{~nm}$.

Based on this, it is possible to infer that the MFC/NFC morphology favors its dispersion in polymeric matrices during the composites production. However, agglomeration of these structures may occur, as seen in figure 1. As the MFC/NFC individualization intensifies, there is a significant increase in the specific material surface (Zhang et al. 2018a; Silva et al. 2021). Consequently, the number of hydrogen bonds between the celulose hydroxylic groups $(-\mathrm{OH})$ with the reactive groups of the polymer matrix increases significantly. The result is greater cohesion between the materials and improvement in the physical and mechanical properties of the final product (Wang et al. 2019; Kerche et al. 2021; Panaitescu et al. 2021).

\section{Physical properties of the films}

The films were easily detached from the acrylic plates, presenting a homogeneous and malleable aspect. For all physical properties evaluated, the effect of several MFC/NFC contents was observed and all variables followed a quadratic trend in the regression models adjusted (Fig. 2).

The solids content ranged between 84 and 99\%, being the highest values observed for the films with 50 and $100 \% \mathrm{MFC} / \mathrm{NFC}$ (Fig 2a). The films with other MFC/NFC contents obtained similar standard deviation ranges, except for the film composed of 100\% HPMC, which showed the lowest solids content ( 92\%).

\section{[Insert Fig. 2]}

Fig. 2 Regression models for a) solids content, b) thickness, c) grammage and d) density of HPMC films reinforced with different MFC/NFC contents

Considering that all the films were produced with the same dry mass and the solids content is calculated based on the initial mass of the films in equilibrium moisture, there was a reduction in water adsorption with the addition of MFC/NFC in concentrations higher than 50\%. This was assumed to be due to the establishment of hydrogen bonds between the three-dimensional structure of MFC/NFC and the HPMC matrix. Up to around 50 to 
$70 \%$ of $\mathrm{MFC} / \mathrm{NFC}$, the vapor pressure in the atmosphere where the films were kept until reach equilibrium moisture, was not enough to break the intermolecular hydrogen bonds, resulting in lower water adsorption. Fu and Netravali (2020) found a reduction in water absorption for starch films with addition of $40 \% \mathrm{MFC} / \mathrm{NFC}$. This effect was attributed to the crystalline and three-dimensional structure of MFC/NFC, which forms strong hydrogen bonds with the matrix and prevents the entry of water molecules in the amorphous regions of the cellulose chain.

Larsson et al. (2017) explain that MFC/NFC have more crystalline structure than HPMC, therefore in most cases, it is expected a lower water adsorption in films with higher proportions of MFC/NFC, resulting in higher solids content. However, the authors emphasize that in high content of MFC/NFC, water uptake can be facilitated by spaces present in the three-dimensional network. Films composed of $25 \%$ of MFC/NFC presented the smallest average and the greatest variations for thickness (Fig. 2b), whereas the highest average for thickness was obtained for the films containing $50 \%$ of MFC/NFC. The values obtained for the other treatments did not differ from each other. The variations observed can be explained by the inherent aspects of the casting method. Although this method has been widely used in research with starch and protein-based films, it shows gaps such as: difficulty in producing films in larger dimensions, long drying time, thickness heterogeneity and wrinkling, due to the non-application of vacuum (Retegi et al. 2010; Moraes et al. 2013; Miettinen et al. 2014). Even with this limitation, the observed trends are in agreement with other works in the literature.

Guimarães et al. (2015) and Luchese et al. (2018) observed that increases on the MFC/NFC concentration in biopolymer films cause a gradual increase in thickness. Reduction in thickhness of films with MFC/NFC contents above $50 \%$ can be attributed to the higher mass/volume ratio of filmogenic suspensions. Lago et al. (2020) explained that films with the same mass, but varying the proportion matrix-MFC/NFC, tend to have smaller volumes and thicknesses when the suspensions present greater amounts of MFC/NFC. It is noteworthy that thickness is a relevant variable for characterization of biopolymer composites, because it is directly related to mechanical, optical properties, and barrier to water vapor and other gases (Zhang et al. 2016; Gicquel et al. 2017; Braga et al. 2021).

Regarding the grammage and density, there was a reduction in their values when $25 \%$ of MFC/NFC was added to the HPMC matrix (Fig. 2c, d). Addition of other percentages resulted in gradual increase of values, which provided better models adjustments and explains the higher coefficients of determination $\left(\mathrm{R}^{2}>90 \%\right)$. The greatest variation for grammage and density was observed for pure MFC/NFC films, whereas the smallest variation was found for films composed of $100 \%$ HPMC. Porosity was reduced, as well as the amount of MFC/NFC in the films increased (Fig. 3), confirming the reduction of relation mass/volume, previously discussed. This effect is explained by the lower density of HPCM $\left(\cong 1.02 \mathrm{~g} / \mathrm{cm}^{3}\right)$ in relation to native cellulose $\left(\cong 1.54 \mathrm{~g} / \mathrm{cm}^{3}\right)($ Ghadermazi et al. 2018).

\section{[Insert Fig. 3]}

Fig. 3 Regression models for porosity of HPMC films reinforced with different MFC/NFC contents

MFC/NFC percentages greater than 50\% provide films with higher grammages and densities, thinner, and less porous. The values found for grammage $\left(16\right.$ to $\left.26 \mathrm{~g} / \mathrm{m}^{2}\right)$ and density $\left(0.6\right.$ to $\left.1.2 \mathrm{~g} / \mathrm{cm}^{3}\right)$ and porosity (31 to $52 \%$ ) are in harmony with the literature. Sylverud and Stenius (2009) and Spence et al. (2010) found grammage values ranging from 17 to $35 \mathrm{~g} / \mathrm{m}^{2}$, density ranging from 0.8 to $1.1 \mathrm{~g} / \mathrm{cm}^{3}$ and porosity from 21 to $48 \%$, studying 
MFC/NFC films. Grammage, density and porosity of biocomposites are important parameters regarding water degradation, mechanical and barrier properties, mainly aiming applications in packaging or paper coatings (Youssef and El-Sayed 2018; Fotie et al. 2020; Nechita and Roman 2020).

\section{Morphology of the films}

The micrographs show more regular surface and pore formation in the cross section of the films produced only with HPMC (Figs. 4a and 4b). For films produced with $25 \%$ MFC/NFC, the compatibility matrixreinforcement was verified due to formation of layers, with some isolated MFC/NFC agglomerates (Figs. 4c and 4d). For films composed of 50\% MFC/NFC, there was increase in surface granularity and formation of more cohesive and homogeneous layers along the transversal profile (Figs. 4e and $4 \mathrm{f}$ ).

\section{[Insert Fig. 4]}

Fig. 4 SEM micrographs of HPMC films reinforced with different contents of MFC/NFC; a) 100\% HPMCsurface; b) 100\% HPMC - cross section; c) 25\% MFC/NFC - surface; d) 25\% MFC/NFC - cross section; e) $50 \%$ MFC/NFC - surface; f) 50\% MFC/NFC - cross section; g) 75\% MFC/NFC - surface; h) 75\% MFC/NFC - cross section; i) $100 \% \mathrm{MFC} / \mathrm{NFC}$ - surface; j) $100 \% \mathrm{MFC} / \mathrm{NFC}$ - cross section

Films with $75 \%$ of MFC/NFC showed more prominent granularity (Fig. 4g). This composition presented organization in layers, with some pores and nanofibril aggregates along the film profile, indicating a heterogeneous distribution of material (Fig. 4h). Films composed only of MFC/NFC also presented surface irregularity (greater granularity) and discontinuous layers (Figs. $4 \mathrm{i}$ and $4 \mathrm{j}$ ). The presence of HPMC between 25 and $50 \%$ in the films composition, prevented the formation of MFC/NFC aggregates in larger dimensions and allowed the formation of layers, reducing the pores size. Furthermore, smaller diameters of the MFC/NFC also contribute to a decrease in porosity due to the filling of empty spaces in the matrix (Minelli et al. 2010; Larsson et al. 2012; Lavoine et al. 2014).

Observing the general films appearance and the cracks absence, it can be said that there was high miscibility between the HPMC matrix and the dispersed phase of MFC/NFC, even without application of compatibilizers or plasticizers. The use of MFC/NFC make it possible to obtain bionanocomposites with no need of aggressive chemical additives, resulting in lower cost and obtaining eco-friendly materials (He et al. 2020; Kuzmanovic et al. 2021). MFC/NFC tend to show high miscibility and low agglomeration in matrices which molecular structures have functional groups that enhance the hydrogen bonds formation (Tian et at. 2020; Olonisakin et al. 2021; Zhang et al. 2021).

\section{Transparency of the films}

The variation of films transparency fit the quadratic model (Fig. 5). It was observed that up to 50\% MFC/NFC, the averages of transparencies were similar, being reduced from 81 to $63 \%$ for higher contents.

\section{[Insert Fig. 5]}

Fig. 5 Transparency of HPMC films reinforced with different MFC/NFC contents 
This fact can be attributed to the increase in surface granularity of the films caused by the addition of MFC/NFC, as observed in the SEM micrographs (Fig. 4). The optical properties are directly affected by granularity, roughness and presence of MFC/NFC aggregates on their surfaces (Ng et al. 2020; Chen et al. 2021b). This effect is intensified when the MFC/NFC amount in the film matrix is increased, reducing the transparency (Kumar et al. 2014; Lyytikainen et al. 2021; Tian et al. 2021).

Another parameter that influences the film transparency is cellulose crystalline structure (Zheng et al. 2021). Zhang et al. (2015) state that cellulose aggregates composed of small grains of crystals provide greater light scattering, resulting in lower transparency. Although both materials used in the production of films are derived from cellulose, the crystallinity index of HPMC is around 39\% (Zhang et al. 2018b; Zhang et al. 2020), whereas the Pinus MFC/NFC presents crystallinity index around 60\% (Dias et al. 2019), also explaining the differences observed in the films transparency.

\section{Water vapor permeability}

Analysis of variance did not show statistical differences for WVTR and WVP of the films produced. This may have occurred due to variations observed for values, especially for films produced with 75\% MFC/NFC (Figs. 6a and 6b). However, it is possible to note a trend to reduce WVTR and WVP, with the addition of 50 and $75 \%$ of MFC/NFC, respectively.

Fig. 6 Water vapor transmission rate (WVTR) and water vapor permeability (WVP) of HPMC films reinforced with different MFC/NFC contents

These results are related to porosity reduction and increase in film thickness as the amount of MFC/NFC was increased. HPMC films produced by casting tend to have greater WVP, due to the heterogeneity of the film surface (Aydogdu et al. 2019). Vapor penetration can be reduced with addition of oils, polymers, proteins, chitosan nanoparticles, micro/nanocellulose and minerals (Larsson et al. 2012; Choi et al. 2016; Aydogdu et al. 2018).

Hassan et al. (2018) observed that films of rice straw NFC presented higher or equal WVP, than those of HPMC. However, after the addition of NFC in range of 10 to $75 \%$, there was a decrease in WVP of around 10 to $18 \%$. In other words, the presence of NFC together with HPMC hindered the moisture diffusion through the film. Thus, it can be said that the results found were lower than those reported in the literature. Hassan et al. (2018) found values of WVP in the order of 6 and $8 \mathrm{~g} \mathrm{~mm} \mathrm{kPa}^{-1} \mathrm{day}^{-1} \mathrm{~m}^{-2}$, respectively, for pure HPMC and NFC films. Lopes et al. (2018) found values of WVP ranging from 8 to $12 \mathrm{~g} \mathrm{~mm} \mathrm{kPa}^{-1} \mathrm{day}^{-1} \mathrm{~m}^{-2}$, and from 8 to $10 \mathrm{~g} \mathrm{~mm} \mathrm{kPa}^{-}$ ${ }^{1}$ day $^{-1} \mathrm{~m}^{-2}$ for MFC/NFC films of Pinus sp and Eucalyptus sp., respectively. Rosenbloom and Zhao (2021) obtained values of WVP from 7 to $14 \mathrm{~g} \mathrm{~mm} \mathrm{kPa}^{-1} \mathrm{day}^{-1} \mathrm{~m}^{-2}$ for HPMC films reinforced with cellulose nanocrystals in concentration from 2 to $6 \%$.

An important point to mention is that the films WVP is important for being evaluated, but it is not a restrictive factor. In applications as fresh vegetable-based food, permeable films can be used, whereas films with low permeability can be indicated for foods and dehydrated products (Prado et al. 2017). 


\section{Degradation in water of the films}

For degradation in water of the films, there was a significant effect of the addition of different MFC/NFC contents with values linearly decreasing as well as the MFC/NFC content was increased (Fig 7). The lowest average for degradation in water was observed for films produced only with MFC/NFC, whereas the highest value was found for the composition of $25 \% \mathrm{MFC} / \mathrm{NFC}$. The greatest variations in this parameter were observed for films composed only by HPMC.

\section{[Insert Fig. 7]}

Fig. 7 Regression model for degradation in water of HPMC films reinforced with different MFC/NFC contents

When HPMC comes into contact with water, the hydration process quickly occurs, leading to a transition from vitreous to elastic state, which results in formation of a gel with the water (Kiss et al. 2019). HPMC has a large amount of hydroxyl groups on its surface, which absorb large amounts of molecules and disperse the matrix (Ci et al. 2020).

Degradation in water was reduced by increasing the amount of MFC/NFC in the HPMC matrix because cellulose is insoluble in water due to its crystallinity (Belbekhouche et al. 2011). In addition, the hydrogen bonds established by the hydroxylic groups in the microfibril network and with the matrix, occur in greater quantity being stronger and more stable (Hassan et al. 2018; Nguyen and Lee 2021), reducing the degradation in water of the films.

Corroborating this, Larsson et al. (2017) stated that structures composed of HPMC and MFC/NFC suffer dissociation of micro/nanofibrils and HPMC network, with the water entry into empty spaces. Thus, the hydrated HPMC will be diluted to lower concentrations and may untangle and diffuse out of the films.

\section{Contact angle, wettability and grease resistance}

The analysis of variance did not show differences between the averages for contact angle. For the compositions 75 and $100 \%$ MFC/NFC, the smallest variations in the values of this parameter were observed (Fig. 8a). Only the films composed of $25 \% \mathrm{MFC} / \mathrm{NFC}$ presented contact angles greater than $90^{\circ}$. The wettability followed a quadratic trend (Fig. 8b), being the lowest averages observed for films composed of 100\% HPMC and $25 \% \mathrm{MFC} / \mathrm{NFC}$.

\section{[Insert Fig. 8]}

Fig. 8 a) Contact angle and b) regression model for wettability of HPMC films reinforced with different MFC/NFC contents

Regarding the wettability, the highest values were obtained for films produced with 50 and $75 \%$ MFC/NFC, respectively. This result can be explained by the greater granularity of these films surface (see Figures $4 \mathrm{e}$ and $4 \mathrm{~g}$ ). As the film surface granularity increases, the contact angle and wettability are reduced (Dankovich and Gray 2011). This is explained by the increase of the film contact surface with water, generating different intensities of adhesion forces that overcome the cohesion forces between the water molecules, favoring their spreading (Mohan et al. 2011; Grundke et al. 2015; Tang et al. 2016). Furthermore, in dry films, the access of water to MFC/NFC hydroxylic groups is hampered due to establishment of numerous hydrogen bonds between 
the cellulose chains. Thus, there is greater exposure of the axial direction of the glucopyranose ring, which is hydrophobic due to the C-H bonds between the pyranoside groups ( $\mathrm{Li}$ et al. 2013; Faria-Tischer et al. 2015).

Taking into account the classification of the contact angle, values between $0-90^{\circ}$ indicate surfaces susceptible to wetting, whereas contact angle values between $90-180^{\circ}$ classify the material as hydrophobic, and partially lipophilic (Sahraee et al. 2017; Abbasi et al. 2021). Based on results, all films analyzed were hydrophilic. Moreover, the TAPPI T $559 \mathrm{~cm}-12$ standard (TAPPI 2012), allows to classify all the compositions as grease resistant (kit ${ }^{\circ}{ }^{12}$ ), which are in harmony with other studies with HPMC and MFC/NFC films (Ghadermazi et al. 2019; Rosenbloom and Zhao 2020; Cruz et al. 2021; Jin et al. 2021). It can be said that the values obtained for the contact angle and wettability for films with MFC/NFC contents between $50-75 \%$ are compatible to materials with possible paint application on the surface, such as packaging. Scheibe et al. (2014) verified that contact angles between $70-40^{\circ}$ resulted in good water-based paint spread on starch films reinforced with vegetal fibers. Similarly, Lourenço et al. (2020) observed that addition of MFC/NFC-starch in the paper coating resulted in improved printability and pigment retention on the paper surface.

\section{Mechanical properties of the films}

Analysis of variance showed significant effect of MFC/NFC contents added to the films (Figure 9). Tensile strength and Young's modulus followed a quadratic trend, while the elongation at break followed a linear tendency. There was a gradual increase in resistence with higher MFC/NFC contents, highlighting the films composed of 75\% MFC/NFC, with the average tensile strength 70\% higher compared to pure films of HPMC (Fig. 9a). The first derivative of the function shows that the maximum tensile strength (57.7 MPa) could be obtained with the optimum MFC/NFC content of $89.7 \%$.

\section{[Insert Fig. 9]}

Fig. 9 Regression models for a) tensile strength, b) Young's Modulus, c) elongation at break and d) characteristic curves for tensile test of HPMC films reinforced with different MFC/NFC contents

Regarding Young's modulus, there was also an directly proportional increase to higher MFC/NFC contents. Films composed of 75\% and 100\% MFC/NFC stood out with Young's modulus from 6 to 10 times higher compared to pure HPMC films (Fig. 9b).

Films composed of $25 \% \mathrm{MFC} / \mathrm{NFC}$ required greater energy consumption in the MFC/NFC pull-out (Figs. $9 \mathrm{c}$ and $9 \mathrm{~d}$ ). This is an ideal condition for the movement of MFC/NFC into the polymer matrix, which results in higher friction energy between matrix-reinforcement, increasing the film tenacity (Isogai 2013; Jin et al. 2020). On the other hand, with higher MFC/NFC contents in the HPMC matrix, formation of interfibrillary hydrogen bonds was favored (Silva et al. 2021), which offer greater slip resistance than MFC/NFC, increasing the stiffness and mechanical strength of the films (Benítez et al. 2013) (see Figure 10).

\section{[Insert Fig. 10]}

Fig. 10 Scheme showing the increase of film stiffness and reduction of slippage with greater amounts of MFC/NFC in the HPMC matrix 
Krishnadev et al. (2021) verified an increase in tensile strength with the addition of $1 \%$ (w/v) of NFC to the HPMC matrix, obtaining values for tensile strength, Young's modulus and elongation at break around $14 \mathrm{MPa}$, $14 \mathrm{MPa}$ and 12\%, respectively. Prado et al. (2017) produced HPMC films reinforced with CNC contents from 1 to $10 \%$ and found tensile strength between 35.5 - 39.6 MPa, Young's modulus ranging from 13.1 to 13.4 MPa and elongation at break between 21.3 - 25.2\%. Hassan et al. (2018) obtained tensile strength around 3, 4 and $8 \mathrm{MPa}$ for HPMC films reinforced with NFC contents of 10, 50 and 75\% (w/v), respectively. The Young's modulus results found by these authors were approximately 150, 170 and $350 \mathrm{MPa}$ for contents of 10, 50 and $75 \%$ (w/v) of NFC, respectively.

Orasugh et al. (2018a) achieved 88 and 100\% of increase for tensile strength and Young's modulus, respectively, when adding 1\% (w/v) NFC to the HPMC matrix. Likewise, Bilbao-Sáinz et al. (2010) reportaram aumentos de 22 e 55\% para tensile strength and Young's modulus, respectively, studying films obtained with a ratio 3:0.8 between HPMC and microcrystalline cellulose (MCC). The results of the present work were highly superior to those from the studies presented. However, all of them presented the same relationship between the increase in MFC/NFC contents and improvement in mechanical properties.

\section{Principal Component Analysis (PCA) and Pearson Correlation}

The perceptual map (Figure 11) showed that the first component (PC1) explains 50.9\% of the data variability, whereas $19.4 \%$ was explained by the second component (PC2). Therefore, the dimensional perceptual map was suitable to assess the relationship between the studied variables, as the components sum exceeded $70 \%$, explaining a large part of the variance.

\section{[Insert Fig. 11]}

Fig. 11 Principal Component Analysis (PCA) for physical, optical, barrier and mechanical properties, and grouping of HPMC films reinforced with different MFC/NFC contents

High dispersion of values was observed for pure HPMC films and for those containing 25\% MFC/NFC, which were grouped at the right of the perceptual map without overlapping. The values obtained for films composed of $75 \%$ (high dispersion) and $100 \%$ MFC/NFC (low dispersion) were grouped at the left with overlaps between the groups, suggesting similarity among them. The values for films produced with 50\% MFC/NFC were positioned at the center of the perceptual map, with low dispersion, indicating intermediate values for physical, optical, surface and mechanical parameters among the studied compositions.

Based on the direction and sense of the eigenvectors, it was noted that the studied parameters varied among all treatments on the multivariate space. Pure HPMC films tend to have higher porosity, transparency and WVP values, while films produced with $25 \%$ MFC/NFC have higher values for degradation in water, elongation at break and contact angle. Films produced with 50\% MFC/NFC may be thicker and permeable to water vapor. Films produced with 75 and 100\% MFC/NFC have higher values for density, solids content, wettability, tensile strength and Young's modulus.

Strong correlations can be observed between physical, mechanical, optical and surface properties (Figure 12). When producing films with higher densities, that is, with higher MFC/NFC contents, there was an increase in tensile strength and Young's modulus, whereas WVP, water degradation, porosity, transparency and elongation at 
484

485

486

487

488

489

490

491

492

493

494

495

496

497

498

499

500

501

502

503

504

505

506

507

508

509

510

511

512

513

514

515

516

517

518

519

520

521

522

523

break were reduced. Films with higher densities have smaller spaces for water and/or vapor to penetrate, resulting in lower permeability (Bras et al. 2011; Yang et al. 2011; Tanpichai et al. 2019).

\section{[Insert Fig. 12]}

Fig. 12 Correlogram for Pearson correlation between physical, optical, barrier and mechanical properties of HPMC films reinforced with different MFC/NFC contents

Density has a strong positive correlation with mechanical properties of cellulose-based materials (Walther et al. 2020). The correlation between the increase in transparency and the reduction in resistance is explained by the increase on crystallinity index and films granularity. MFC/NFC have higher crystallinity index than HPMC, reducing the light passage through films with higher MFC/NFC contents and more irregular surface (Orasugh et al. 2018b; Xu et al. 2018).

Considering the degradation in water presented by films composed of $25 \%$ MFC/NFC it can be said that the studied films could be applied for single-use packaging (Krishnadev et al. 2021). On the other hand, taking into account the films application in cases where the water vapor diffusion between the atmosphere and the package interior is not interesting, the films composed of 75 and $100 \%$ presented superior characteristics among the films studied. In addition, the mentioned compositions presented greater predictability regarding its physical integrity and mechanical behavior when compared to films with MFC/NFC contents below 50\%. Idumah et al. (2019) and Jin et al. (2021) reported that HPMC and MFC/NFC have the potential to develop functions to improve mechanical and barrier properties in several packaging applications, especially considering the requirements associated with protection and shelf life of the products.

\section{Conclusion}

In this research, MFC/NFC from Pinus sp. have been successfully incorporated as reinforcing material for development of clear HPMC films. Homogeneous dispersion, nanometric dimensions and good compatibility between MFC/NFC reinforcement and matrix were confirmed by SEM. Considering only the films composed of 75\% MFC/NFC, it was observed the highest grammage and density, better mechanical properties and higher opacity. For this composition it was also observed lower transparency, and degradation in water. The wettability were higher for films produced with 50 and 75\% MFC/NFC. Films composed of $75 \%$ and $100 \%$ MFC/NFC presented Young's modulus from 6 to 10 times higher compared to pure HPMC films. PCA showed that Pure HPMC films tend to have higher porosity, transparency and WVP values, while films produced with $25 \%$ MFC/NFC have higher values for degradation in water, elongation at break and contact angle. All films analyzed were classified as hydrophilic, as no waterproofing treatment was carried out, and with high grease resistance. Based on the results obtained, the HPMC films reinforced with MFC/NFC showed potential to be used as packaging material and special papers.

\section{Acknowledgments}

We are especially grateful to the Postgraduate Program in Wood Science and Technology (PPGCTM) and Biomaterials Engineering (PPGBIOMAT), both from Federal University of Lavras (UFLA) for the provision of study material and infrastructure. We would also like to thank the Conselho Nacional por Desenvolvimento 

scholarship finance code 0022.0279.1202.0016/2021 - PROPESP.

\section{Author Contributions}

A.R.P.Mascarenhas: Contributed with the writing of the initial version, review, data collection, and data analysis.

M.V. Scatolino and A.A. dos Santos: Were contributors in writing the manuscript, specifically writing the initial version and review, and editing of the manuscript. L.B. Norcino and P.J. Duarte: Contributed with the microscope images. R.R. Melo: Contributed with the text review and data analysis. M.C. Dias and C.E.T. de Faria contributed with the TEM and SEM micrographs. M.C. Mendonça: Contributed with the tests of wettability and contact angle. G.H.D. Tonoli: Contributed with supervision, conceptualization, funding acquisition, and project administration. All authors read and approved the final manuscript. All authors have approved the final version of the manuscript.

\section{Funding}

The research was funded by CNPq and CAPES.

\section{Declarations}

\section{Conflicts of interest None.}

Consent to participate The authors' participation was authorized during the construction of the study.

Consent for publication All authors agree with the publication of the article in this journal.

\section{References}

Abbasi H, Fahim H, Mahboubi M (2021) Fabrication and characterization of composite film based on gelatin and electrospun cellulose acetate fibers incorporating essential oil. Journal of Food Measurement and Characterization 15:2108-2118. https://doi.org/10.1007/s11694-020-00799-1

Abdekhamid HN, Mathew AP (2022) Cellulose-metal organic frameworks (CelloMOFs) hybrid materials and their multifaceted Applications: A review. Coordination Chemistry Reviews 451: 214263.

555 https://doi.org/10.1016/j.ccr.2021.214263

Amato-Lourenço LF, Galvão LS, Weger LA, Hiemstra PS, Vijver MG, Mauad T (2020) An emerging class of air pollutants: Potential effects of microplastics to respiratory human health? Science of The Total Environment 749: 141676. https://doi.org/10.1016/j.scitotenv.2020.141676

American Society for Testing and Materials - ASTM (2012) Standard Practice for Maintaining Constant Relative Humidity by Means of Aqueous Solutions. ASTM E104-02. West Conshohocken.

American Society for Testing and Materials - ASTM (2015) Standard Test Method for Transparency of Plastic Sheeting. ASTM D1746-15. West Conshohocken. 
Aydogdu A, Sumnu G, Sahin S (2018) A novel electrospun hydroxypropyl methylcellulose/polyethylene oxide blend nanofibers: Morphology and physicochemical properties. Carbohydrate Polymers 181:234-246. https://doi.org/10.1016/j.carbpol.2017.10.071

Aydogdu A, Yildiz E, Ayhan Z, Aydogdu Y, Sumnu G, Sahin S (2019) Nanostructured poly(lactic acid)/soy protein/HPMC films by electrospinning for potential applications in food industry. European Polymer Journal 112: 477-486. https://doi.org/10.1016/j.eurpolymj.2019.01.006

Belbekhouche S, Bras J, Siqueira G, Chappey C, Lebrun L, Khelifi B, Marais S, Dufresne A (2011) Water sorption behavior and gas barrier properties of cellulose whiskers and microfibrils films. Carbohydrate Polymers 83: 1740-1748. https://doi.org/10.1016/j.carbpol.2010.10.036

Benítez AJ, Torres-Rendon J, Poutanen M, Walther A (2013) Humidity and multiscale structure govern mechanical properties and deformation modes in films of native cellulose nanofibrils. Biomacromolecules 14:4497-4506. https://doi.org/10.1021/bm401451m

Bilbao-Sáinz C, Avena-Bustillos RJ, Wood DF, Williams TG, Mchugh TH (2010) Composite edible films based on hydroxypropyl methylcellulose reinforced with microcrystalline cellulose nanoparticles. Journal of Agricultural and Food Chemistry 58:3753-3760. https://doi.org/10.1021/jf9033128

Bilbao-Sáinz C, Bras J, Williams T, Sénechal T, Orts W. (2011) HPMC reinforced with different cellulose nanoparticles. Carbohydrate Polymers 86:1549-1557. https://doi.org/10.1016/j.carbpol.2011.06.060

Blasiak R, Leander E, Jouffray JB, Virdin J (2021) Corporations and plastic pollution: Trends in reporting. Sustainable Futures 3: 100061. https://doi.org/10.1016/j.sftr.2021.100061

Braga DG, Abreu JLL, Silva M (2021) Cellulose nanostructured films from pretreated açai mesocarp fibers: physical, barrier, and tensile performance. Cerne 27: e-102783. https://doi.org/10.1590/01047760202127012783

Bras J, Viet D, Bruzzese C, Dufresne A (2011) Correlation between stiffness of sheets prepared from cellulose whiskers and nanoparticles dimensions. Carbohydrate Polymers 84:211-215.

https://doi.org/10.1016/j.carbpol.2010.11.022

Chen Y, Awasthi AK, Wei F, Tan Q, Li J (2021a) Single-use plastics: production, usage, disposal, and adverse impacts. Science of The Total Environment 752: 141772. https://doi.org/10.1016/j.scitotenv.2020.141772

Chen C, Zong L, Wang J, Xie J (2021b) Microfibrillated cellulose reinforced starch/polyvinyl alcohol antimicrobial active films with controlled release behavior of cinnamaldehyde. Carbohydrate Polymers 272: 118448. https://doi.org/10.1016/j.carbpol.2021.118448

Chinga-Carrasco G, Yu Y, Diserud O (2011) Quantitative Electron Microscopy of Cellulose Nanofibril Structures from Eucalyptus and Pinus radiata Kraft Pulp Fibers. Microscopy and Microanalysis 17:563 - 571. https://doi.org/10.1017/S1431927611000444

Choi WS, Singh S, Lee YS (2016) Characterization of edible film containing essential oils in hydroxypropyl methylcellulose and its effect on quality attributes of 'Formosa' plum (Prunus salicina L.). LWT - Food Science and Technology 70:213-222. https://doi.org/10.1016/j.lwt.2016.02.036

Ci M, Liu J, Shang S, Jiang Z, Zhu P, Sui S (2020) The effect of HPMC and CNC on the structure and properties of alginate fibers. Fiber and Polymers 21:2179-2185. https://doi.org/10.1007/s12221-020-1264-z

Cox KD, Covernton GA, Davies HL, Dower JF, Juanes F, Dudas SE (2020) Correction human consumption of microplastics. Environmental Science \& Technology 54: 10974. https://doi.org/10.1021/acs.est.0c04032

Cruz TM, Mascarenhas ARP, Scatolino MV, Faria DL, Matos LC, Duarte PJ, Neto JM, Mendes LM, Tonoli GHD (2021) Hybrid films from plant and bacterial nanocellulose: mechanical and barrier properties. Nordic Pulp \& Paper Research Journal in press. https://doi.org/10.1515/npprj-2021-0036

Dankovich TA, Gray DG (2011) Contact Angle Measurements on Smooth Nanocrystalline Cellulose (I) Thin Films. Journal of Adhesion Science and Technology 25:699-708. https://doi.org/10.1163/016942410X525885

Desmaisons J, Boutonnet E, Rueff M, Dufresne A, Bras J (2017) A new quality index for benchmarking of different cellulose nanofibrils. Carbohydrate Polymers 174:318-329. https://doi.org/10.1016/j.carbpol.2017.06.032

Dias MC, Mendonça MC, Damásio RAP, Zidanes UL, Mori FA, Ferreira SR, Tonoli GHD (2019) Influence of hemicellulose content of Eucalyptus and Pinus fibers on the grinding process for obtaining cellulose micro/nanofibrils. Holzforschung 73:1035-1046. https://doi.org/10.1515/hf-2018-0230 
Faria-Tischer PCS, Tischer CA, Heux L, Denmat SL, Picart C, Sierakowski MR, Putaux JL (2015) Preparation of cellulose II and III films by allomorphic conversion of bacterial cellulose I pellicles. Materials Science and Engineering C 51:167:173. DOI: 10.1016/j.msec.2015.02.025

Ferreira DF (2019) Sisvar: a computer analysis system to fixed effects split plot type designs. Revista Brasileira de Biometria 37: 529-535. https://doi.org/10.28951/rbb.v37i4.450

Foster EJ, Moon RJ, Agarwal UP, Bortner MJ, et al. (2018) Current characterization methods for cellulose nanomaterials. 47: 2609-2679. https://doi.org/10.1039/C6CS00895J

Fotie G, Limbo S, Piergiovanni L (2020) Manufacturing of Food Packaging Based on Nanocellulose: Current Advances and Challenges. Nanomaterials 10:1726. https://doi.org/10.3390/nano10091726

Fu D, Netravali AN (2020) Green composites based on avocado seed starch and nano-and micro-scale cellulose. Polymer Composites 1-18. https://doi.org/10.1002/pc.25739

Ghadermazi R, Hamdipour S, Sadeghi K, Ghadermazi R, Asl AK (2019) Effect of various additives on the properties of the filmes and coatings derived from hydroxypropyl methylcellulose - A review. Food Science \& Nutrition, 7:3363-3377. https://doi.org/10.1002/fsn3.1206

Gicquel E, Martin C, Yanez JG, Bras J (2017) Cellulose nanocrystals as new bio-based layer for improving fiber-based mechanical and barrier properties. Journal of Materials Science 52:3048-3061. https://doi.org/10.1007/s10853-016-0589-x

González I, Boufi S, Pèlach MA, Alcala M, Vilaseca F, Mutjé P (2012) Nanofibrillated cellulose as paper additive in Eucalyptus pulps. BioResources 7: 5167-5180. https://doi.org/10.15376/biores.7.4.5167-5180

Groh KJ, Backhaus T, Carney-Almroth B, Geueke B, Inostroza PA, Lennquist A, Leslie HA, Maffini M, Slunge D, Trasande L, Warhurst M, Muncke J (2019) Science of The Total Environment 651: 3253-3268. https://doi.org/10.1016/j.scitotenv.2018.10.015

Grundke K, Pöschel K, Synytska A, Frenzel R, Dreschsler A, Nitschke M, Cordeiro AL, Uhlmann P, Welzel PB (2015) Experimental studies of contact angle hysteresis phenomena on polymer surfaces — Toward the understanding and control of wettability for different applications. Advances in Colloid and Interface Science 222:350-376. https://doi.org/10.1016/j.cis.2014.10.012

Guimarães M, Botaro VR, Novack KM, Teixeira FG, Tonoli, GHD (2015) Starch/PVA-based nanocomposites reinforced with bamboo nanofibrils. Industrial Crops and Products 70: 72-83. https://doi.org/10.1016/j.indcrop.2015.03.014

Hassan EA, Fadel SM, Hassan ML (2018) Influence of TEMPO-oxidized NFC on the mechanical, barrier properties and nisin release of hydroxypropyl methylcellulose bioactive films. International Journal of Biological Macromolecules, 113:616-622. https://doi.org/10.1016/j.ijbiomac.2018.02.140

He L, Song F, Li DF, Zhao X, Wang XL, Wang YZ (2020) Strong and Tough Polylactic Acid Based Composites Enabled by Simultaneous Reinforcement and Interfacial Compatibilization of Microfibrillated Cellulose. ACS Sustainable Chemistry \& Engineering 8: 1573-1582. https://doi.org/10.1021/acssuschemeng.9b06308

Hu F, Zeng J, Cheng Z, Wang X, Wang B, Zeng Z, Chen K. Cellulose nanofibrils (CNFs) produced by different mechanical methods to improve mechanical properties of recycled paper. Carbohydrate Polymers 254: 117474. https://doi.org/10.1016/j.carbpol.2020.117474

Idumah CI, Hassan A, Ihuoma DE (2019) Recently emerging trends in polymer nanocomposites packaging materials. Polymer-Plastics Technology and Materials 58: 1054-1109. https://doi.org/10.1080/03602559.2018.1542718

Isogai A (2013) Wood nanocelluloses: fundamentals and applications as new bio-based nanomaterials. Journal of Wood Science 59:449-459. https://doi.org/10.1007/s10086-013-1365-Z

Jin S, Li K, Gao Q, Zhang W, Chen H, Li J (2020) Development of conductive protein-based film reinforced by cellulose nanofibril template-directed hyperbranched copolymer. Carbohydrate Polymers 237: 116141. https://doi.org/10.1016/j.carbpol.2020.116141

Jin K, Tang Y, Liu J, Wang J, Ye C (2021) Nanofibrillated cellulose as coating agent for food packaging paper. International Journal of Biological Macromolecules 168: 331-338. https://doi.org/10.1016/j.ijbiomac.2020.12.066 
Kerche EF, Bock DN, Delucis RA, Magalhães WLE, Amico SC (2021) Micro fibrillated cellulose reinforced bio-based rigid high-density polyurethane foams. Cellulose 28: 4313-4326. https://doi.org/10.1007/s10570-02103801-1

Khalil HPSA, Chong EWN, Owolabi FAT, Asniza M, Tye YY, Rizal S, Fazita MRN, Haafiz MKM, Nurmiati Z, Paridah MT (2018) Enhancement of basic properties of polysaccharide-based composites with organic and inorganic fillers: A review. Journal of Applied Polymer Science 136: 47251. https://doi.org/10.1002/app.47251

Kiss T, Alapi T, Varga G, Bartos C, Ambrus R, Szabo-Révész S, Katona G (2019) Interaction studies between levodopa and different excipients to develop coground binary mixtures for intranasal application. Journal of Pharmaceutical Sciences 108: 2552-2560. https://doi.org/10.1016/j.xphs.2019.03.005

Krishnadev P, Subramanian KS, Lakshmanan A, Ganapathy S, Raja K, Rajkishore SK (2021) Hydroxypropyl Methylcellulose Nanocomposites Containing Nano Fibrillated Cellulose (NFC) from Agave americana L. for food packaging applications. BioResources 16: 8125-8151.

Kumar V, Bollström R, Yang A, Chen Q, Chen G, Salminen P, Bousfield D, Toivakka M (2014) Comparison of nano and microfibrillated cellulose films. Cellulose, 21: 3443-3456. https://doi.org/10.1007/s10570-014-0357-5

Kuzmanovic M, Delva L, Cardon L, Ragaert K (2021) The feasibility of using the mfc concept to upcycle mixed recycled plastics. Sustainability 13: 689. https://doi.org/10.3390/su13020689

Lago RC, Oliveira ALM, Dias MC, Carvalho EEN, Tonoli GHD, Boas EVBV (2020) Obtaining cellulosic nanofibrils from oat straw for biocomposite reinforcement: Mechanical and barrier properties. Industrial Crops \& Products, 148:112264. https://doi.org/10.1016/j.indcrop.2020.112264

Larsson M, Hjärtstam J, Larsson A (2012) Novel nanostructured microfibrillated cellulose-hydroxypropyl methylcellulose films with large one-dimensional swelling and tunable permeability. Carbohydrate Polymers, 88: 763-771. https://doi.org/10.1016/j.carbpol.2012.01.056

Larsson M, Johnsson A, Gardebjer S, Bordes R, Larsson A (2017) Swelling and mass transport properties of nanocellulose-HPMC composite films. Materials \& Design, 122: 414-421. https://doi.org/10.1016/j.matdes.2017.03.011

Lavers JL, Dicks L, Dicks MR, Finger A (2019) Significant plastic accumulation on the Cocos (Keeling) Islands, Australia. Scientific Reports 9: 7102. https://doi.org/10.1038/s41598-019-43375-4

Lavoine N, Desloges I, Khelifi B, Bras J (2014) Impact of different coating processes of microfibrillated cellulose on the mechanical and barrier properties of paper. Journal of Materials Science, 49: 2879-2893. https://doi.org/10.1007/s10853-013-7995-0

Le S, Josse J, Husson F (2008) FactoMineR: An R Package for Multivariate Analysis. Journal of Statistical Software 25: 1-18. https://doi.org/10.18637/jss.v025.i01

Leal Filho W, Hunt J, Kovaleva M (2021) Garbage patches and their environmental implications in a plastisphere. Journal of Marine Science and Engineering 9: 1289. https://doi.org/10.3390/jmse9111289

Lengowski EC, Muñiz GIB, Andrade AS, Simon LC, Nisgoski S (2018) Morphological, physical and thermal characterization of microfibrillated cellulose. Revista Árvore 42: e420113. http://dx.doi.org/10.1590/180690882018000100013

Li L, Roethel S, Breedveld V, Hess DW (2013) Creation of low hysteresis superhydrophobic paper by deposition of hydrophilic diamond-like carbon films. Cellulose 20: 3219-3226. https://doi.org/10.1007/s10570013-0078-1

Li YY, Wang B, Ma MG, Wang B (2018) Review of recent development on preparation, properties, and applications of cellulose-based functional materials. International Journal of Polymer Science 2018: 8973643. https://doi.org/10.1155/2018/8973643

Li K, Mcgrady D, Zhao X, Ker D, Tekinalp H, He X, Qu J, Aytug T, Cakmak E, Phipps J, Ireland S, Kunc V, Ozcan S (2021) Surface-modified and oven-dried microfibrillated cellulose reinforced

biocomposites: Cellulose network enabled high performance. Carbohydrate Polymers 256: 117525. https://doi.org/10.1016/j.carbpol.2020.117525

Lindström T, Österberg F (2020) Evolution of biobased and nanotechnology packaging - a review. Nordic Pulp \& Paper Research Journal 35: 491-515. https://doi.org/10.1515/npprj-2020-0042 
Lopes TA, Bufalino L, Claro PIC, Martins MA, Tonoli GHD, Mendes LM (2018) The effect of surface modifications with corona discharge in Pinus and Eucalyptus nanofibril films. Cellulose, 25: 50-17. https://doi.org/10.1007/s10570-018-1948-3

Lourenço AF, Gamelas JAF, Sarmento P, Ferreira PJT (2020) Cellulose micro and nanofibrils as coating agent for improved printability in office papers. Cellulose, 27: 6001-6010. https://doi.org/10.1007/s10570-020-031849

Luchese CL, Garrido T, Spada JC, Tessaro IC (2018) Development and characterization of cassava starch films incorporated with blueberry pomace. International Journal of Biological Macromolecules, 106: 834-839. https://doi.org/10.1016/j.ijbiomac.2017.08.083

Lyytikainen J, Morits M, Östeberg M, Heiskanen I, Backfolk K (2021) Skin and bubble formation in films made of methyl nanocellulose, hydrophobically modified ethyl(hydroxyethyl)cellulose and microfibrillated cellulose. Cellulose 28: 787-797. https://doi.org/10.1007/s10570-020-03557-0

Miettinen A, Chinga-Carrasco G, Kataja M (2014) Three-dimensional microstructural properties of nanofibrillated cellulose films. International Journal of Molecular Sciences 15: 6423-6440. https://doi.org/10.3390/ijms15046423

Minelli M, Baschetti MG, Doghieri F, Ankerfors M, Lindström T, Siró I, Plackett D (2010) Investigation of mass transport properties of microfibrillated cellulose (MFC) films. Journal of Membrane Science v.358, n.1, p.67-75, 2010. https://doi.org/10.1016/j.memsci.2010.04.030

Mohan T, Kargl R, Doliška A, Vesel A, Köstler S, Ribitsch V, Stana-Kleinschek K (2011) Wettability and surface composition of partly and fully regenerated cellulose thin films from trimethylsilyl cellulose. Journal of Colloid and Interface Science 358: 604-610. https://doi.org/10.1016/j.jcis.2011.03.022

Moraes JO, Scheibe AS, Sereno A, Laurindo JB (2013) Scale-up of the production of cassava starch-based films using tape-casting. Journal of Food Engineering 119: 800-808. https://doi.org/10.1016/j.jfoodeng.2013.07.009

Morais FP, Carta AMMS, Amaral ME, Curto JMR (2021) Micro/nano-fibrillated cellulose (MFC/NFC) fibers as an additive to maximize eucalyptus fibers on tissue paper production. Cellulose 25: 6587-6605. https://doi.org/10.1007/s10570-021-03912-9

Naidu DS, John MJ (2021) Cellulose nanofibrils reinforced xylan-alginate composites: Mechanical, thermal and barrier properties. International Journal of Biological Macromolecules 179: 448-456. https://doi.org/10.1016/j.ijbiomac.2021.03.035

Nechita P, Roman M (2020) Review on polysaccharides used in coatings for food packaging papers. Coatings, 10:566. https://doi.org/10.3390/coatings10060566

Ng HKM, Lim GK, Leo CP (2020) N-modified carbon quantum dot in 3D-network of microfibrillated cellulose for building photoluminescent thin film as tartrazine sensor. Journal of Photochemistry and Photobiology A: Chemistry 389: 112286. https://doi.org/10.1016/j.jphotochem.2019.112286

Nguyen SV, Lee BK (2021) Microfibrillated cellulose film with enhanced mechanical and water-resistant properties by glycerol and hot-pressing treatment. Cellulose, 28: 5693-5705. https://doi.org/10.1007/s10570-02103894-8

Okan M, Aydin HM, Barsbay M. Current approaches to waste polymer utilization and minimization: a review. Journal of Chemical Technology and Biotechnology 94: 8-21. https://doi.org/10.1002/jctb.5778

Olonisakin K, Fan M, Xin-Xiang Z, Ran L, Lin Wensheng L, Zhang W, Wenbin Y (2021) Key improvements in interfacial adhesion and dispersion of fibers/fillers in polymer matrix composites; focus on pla matrix composites. Composite Interfaces 1-50. https://doi.org/10.1080/09276440.2021.1878441

Orasugh JT, Saha NR, Rana D, Sarkar G, Mollik MMR, Chattoapadhyay A, Mitra BC, Mondal D, Ghosh SK, Chattoapadhyay D (2018a) Jute cellulose nano-fibrils/hydroxypropylmethylcellulose nanocomposite: A novel material with potential for application in packaging and transdermal drug delivery system. Industrial Crops \& Products 112:633-643. https://doi.org/10.1016/j.indcrop.2017.12.069

Orasugh JT, Saha NR, Sarkar G, Rana D, Mishra R, Mondal D, Ghosh SK, Chattoapadhyay D (2018b) Synthesis of methylcellulose/cellulose nano-crystals nanocomposites: Material properties and study of sustained release of ketorolac tromethamine. Carbohydrate Polymers 188: 168-180. https://doi.org/10.1016/j.carbpol.2018.01.108

Panaitescu DM, Nicolae CA, Melinte V, Scutaru AL, Gabor AR, Popa MS, Oprea M, Buruiana T (2021) Influence of microfibrillated cellulose and soft biocomponent on the morphology and thermal properties of thermoplastic polyurethanes. Journal of Applied Polymer Science 138: 50951. https://doi.org/10.1002/app.50951 
Perosa M, Guerranti C, Renzi M, Bevilacqua S (2021) Taking the sparkle off the sparkling time. Marine Pollution Bulletin 170: 112660. https://doi.org/10.1016/j.marpolbul.2021.112660

Prado NRT, Raabe J, Mirmehdi S, Hugen LN, Lima LC, Ramos ALS, Guimarães Junior M, Tonoli GHD (2017) Strength improvement of hydroxypropyl methylcellulose/ starch films using cellulose nanocrystals. Cerne, 23: 423-434. https://doi.org/10.1590/01047760201723042303

R Foundation for Statistical Computing - R Core Team (2020) R: A language and environment for statistical computing. https://www.R-project.org/. Accessed 07 set. 2020.

Retegi A, Gabilondo N, Penã C, Zuluanga R, Castro C, Ganãn P, Caba K, Mondragon I (2010) Bacterial cellulose films with controlled microstructure-mechanical property relationships. Cellulose 17: 661-669. https://doi.org/10.1007/s10570-009-9389-7

Rosenbloom RA, Zhao Y (2021) Hydroxypropyl methylcellulose or soy protein isolate-based edible, watersoluble, and antioxidant films for safflower oil packaging. Journal of Food Science 86: 129-139. https://doi.org/10.1111/1750-3841.15543

Saito T, Kimura S, Nishiyama Y, Isogai A (2007) Cellulose nanofibers prepared by TEMPO-mediated oxidation of native cellulose. Biomacromolecules 8: 2485-2491. https://doi.org/10.1021/bm0703970

Sahraee S, Milani JM, Ghanbarzade B, Hamishekar H (2017) Effect of corn oil on physical, thermal, and antifungal properties of gelatin-based nanocomposite films containing nano chitin. LWT - Food Science and Technology 76: 33-39. https://doi.org/10.1016/j.lwt.2016.10.028

Scatolino MV, Bufalino L, Mendes LM, Guimarães Júnior M, Tonoli GHD (2017) Impact of nanofibrilation degree of Eucalyptus and Amazonian hardwood sawdust on physical properties of cellulose nanofibril films. Wood Science and Technology 51: 1095-1115. https://doi.org/10.1007/s00226-017-0927-4

Scheibe AS, Moraes JO, Laurindo JB (2014) Production and characterization of bags from biocomposite films of starch-vegetal fibers prepared by tape casting. Journal of Food Process Engineering, 37: 482-492.

Shen M, Huang W, Chen M, Song B, Zeng G, Zhang Y (2020) (Micro)plastic crisis: Un-ignorable contribution to global greenhouse gas emissions and climate change. Journal of Cleaner Production 254: 120138. https://doi.org/10.1016/j.jclepro.2020.120138

Silva LCE, Cassago A, Battirola LC, Gonçalves MC, Portugal RV (2020) Specimen preparation optimization for size and morphology characterization of nanocellulose by TEM. Cellulose, 27:5435-5444. https://doi.org/10.1007/s10570-020-03116-7

Silva LE, Santos AA, Torres L, McCaffrey Z, Klamczynski A Glenn G, Neto ARS, Wood D, Wiliams T, Orts W, Damásio RAP, Tonoli GHD (2021) Redispersion and structural change evaluation of dried microfibrillated cellulose. Carbohydrate Polymers 252:117165. https://doi.org/10.1016/j.carbpol.2020.117165

Sothornvit R, Hong SI, An DJ, Rhim JW (2010) Effect of clay content on the physical and antimicrobial properties of whey protein isolate/organo-clay composite films. LWT - Food Science and Technology 43:279284. https://doi.org/10.1016/j.lwt.2009.08.010

Spence KL, Venditti RA, Habibi Y, Rojas OJ, Pawlak JJ (2010) The effect of chemical composition on microfibrillar cellulose films from wood pulps: Mechanical processing and physical properties. Cellulose 101: 5961-5968, 2010. https://doi.org/10.1007/s10570-010-9424-8

Sylverud K, Stenius P (2009) Strength and barrier properties of MFC films. Cellulose 16: 75-85. https://doi.org/10.1007/s10570-008-9244-2

Tang Z, Li H, Hess DW, Breedveld V (2016) Effect of chain length on the wetting properties of alkyltrichlorosilane coated cellulose-based paper. Cellulose 23: 1401-1413. https://doi.org/10.1007/s10570-0160877-2

Tanpichai S, Witayakran S, Srimarut Y, Woraprayote W, Malila Y (2019) Porosity, density and mechanical properties of the paper of steam exploded bamboo microfibers controlled by nanofibrillated cellulose. Journal of Materials Research and Technology 8: 3612-3622. https://doi.org/10.1016/j.jmrt.2019.05.024

Technical Association of the Pulp and Paper Industry - TAPPI (2012) Grease resistance test for paper and paperboard. T $559 \mathrm{~cm}-12$. TAPPI Press, Norcross.

Technical Association of the Pulp and Paper Industry - TAPPI (2013) Grammage of paper and paperboard. T 410 om-08. TAPPI Press, Norcross. 
Technical Association of the Pulp and Paper Industry - TAPPI (2014) Surface wettability of paper (angle of contact method). T $458 \mathrm{~cm}-14$. TAPPI Press, Norcross.

Technical Association of the Pulp and Paper Industry - TAPPI (2015) Thickness of paper, paperboard, and combined board. T 411 om-15. TAPPI Press, Norcross.

Technical Association of the Pulp and Paper Industry - TAPPI (2021) Standard conditioning and testing atmospheres for paper, board, pulp handsheets, and related products. T 402 sp-21. Tappi Press, Norcross.

Tian Y, Zhu P, Zhou M, Lin Y, Cheng F (2020) Effect of Microfibrillated Cellulose Loading on Physical Properties of Starch/Polyvinyl Alcohol Composite Films. Journal of Wuhan University of Technology-Mater. Sci. Ed. 35: 825-831. https://doi.org/10.1007/s11595-020-2326-1

Tian Y, Zhu P, Zhou M, Guo R, Cheng F, Lin Y, Yang R (2019) Microfibrillated cellulose modified with urea and its reinforcement for starch-based bionanocomposites. Cellulose 26: 5981-5993. https://doi.org/10.1007/s10570-019-02505-x

Tudoroiu EE, Dinu-Pîrvu CE, Kaya MGA, Popa L, Anuta V, Prisada RM, Ghica MV (2021) An overview of cellulose derivatives-based dressings for wound-healing management. Pharmaceuticals 14: 1215. https://doi.org/10.3390/ph14121215

Tundisi LL, Mostaço GB, Carricondo PC, Petri DFS (2021) Hydroxypropyl methylcellulose: Physicochemical properties and ocular drug delivery formulations. 159: 105736. https://doi.org/10.1016/j.ejps.2021.105736

Viana LC, Muniz GIB, Magalhães WLE (2017) Propriedades físicas e mecânicas de filmes nanoestruturados obtidos a partir de polpa Kraft de Pinus sp. não branqueada. Scientia Forestalis 45: 653-662. https://doi.org/10.18671/scifor.v45n116.06

Xu W, Wang X, Sandler N, Willför S, Xu C (2018) Three-Dimensional Printing of Wood-Derived Biopolymers: A Review Focused on Biomedical Applications. ACS Sustainable Chemistry \& Engineering 6:5663-5680. https://doi.org/10.1021/acssuschemeng.7b03924

Zhang BX, Azuma JI, Uyama H (2015) Preparation and characterization of a transparent amorphous cellulose film. RSC Advances 5: 2900-2907. https://doi.org/10.1039/C4RA14090G

Zhang X, Yu Y, Jiang Z, Wang H (2016) Influence of thickness and moisture content on the mechanical properties of microfibrillated cellulose (MFC) films. Wood Research 61:851-860.

Zhang T, Zhang Y, Wang X, Liu S, Yao Y (2018a) Characterization of the nano-cellulose aerogel from mixing CNF and CNC with different ratio. Material Letters 229:103-106. https://doi.org/10.1016/j.matlet.2018.06.101

Zhang, T, Lu, YQ, Peng, YL, Yu, YX, Zhao, Y, Ma, Y, Qjan, JY (2018b) Microstructures and properties of photophobic films composed of hydroxypropyl methylcellulose and different salts. International Journal of Biological Macromolecules 120: 945-951. https://doi.org/10.1016/j.ijbiomac.2018.09.011

Zheng X, Huang F, Chen L, Huang L, Cao S, Ma X (2019) Preparation of transparent film via cellulose regeneration: Correlations between ionic liquid and film properties. Carbohydrate Polymers, 203: 214-218. https://doi.org/10.1016/j.carbpol.2018.09.060

Zhang L, Lu YQ, Qjan JY, Yue LN, Li Q, Xiao LX, Ding XL, Guan CR (2020) Microstructures, physical and sustained antioxidant properties of hydroxypropyl methylcellulose based microporous photophobic films. International Journal of Biological Macromolecules 152: 1002-1009. https://doi.org/10.1016/j.ijbiomac.2018.09.011

Zhang Z, Liu X, Wang H, He H, Bai R (2021) Preparation and characterization of Enteromorpha prolifera nanocellulose/polyvinyl alcohol composite films. Polymer Composites 42: 1712-1726. https://doi.org/10.1002/pc.25926

Yang Q, Fukuzumi H, Saito T, Isogai A, Zhang L (2011) Transparent cellulose films with high gas barrier properties fabricated from aqueous alkali/urea solutions. Biomacromolecules 12: 2766-2771. https://doi.org/10.1021/bm200766v

Youssef AM, El-Sayed SM (2018) Bionanocomposites materials for food packaging applications: Concepts and future outlook. Carbohydrate Polymers 193: 19-27.

Walther A, Lossada F, Benselfelt T, Kriechbaum K, Berglund L, Ikkala O, Saito T, Wagberg L, Bergström L (2020) Best practice for reporting wet mechanical properties of nanocellulose-based materials. Biomacromolecules 21:2536-2540. https://doi.org/10.1021/acs.biomac.0c00330 
867 Walker TR (Micro)plastics and the UN sustainable development goals. Current Opinion in Green and 868 Sustainable Chemistry 30: 100497. https://doi.org/10.1016/j.cogsc.2021.100497

869 Wang J, Liu X, He H, Liu L (2019) Preparation of nanocellulose and its potential in reinforced composites: A 870 review. Journal of Biomaterials Science 30:919-946. https://doi.org/10.1080/09205063.2019.1612726 
Figures

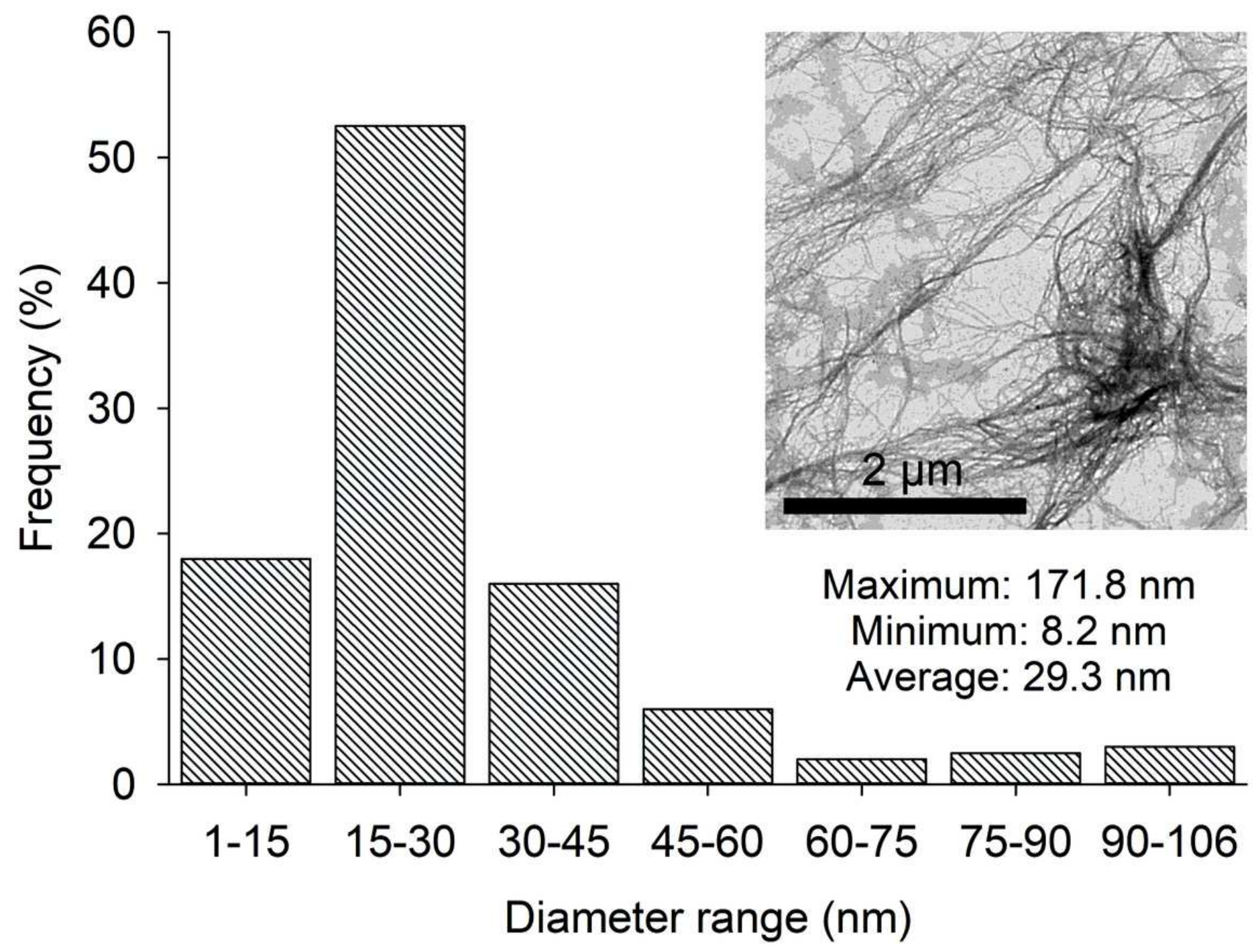

Figure 1

Frequency of diametric distribution of MFC/NFC produced from cellulosic pulp of Pinus sp. subjected to TEMPO mediated oxidation 

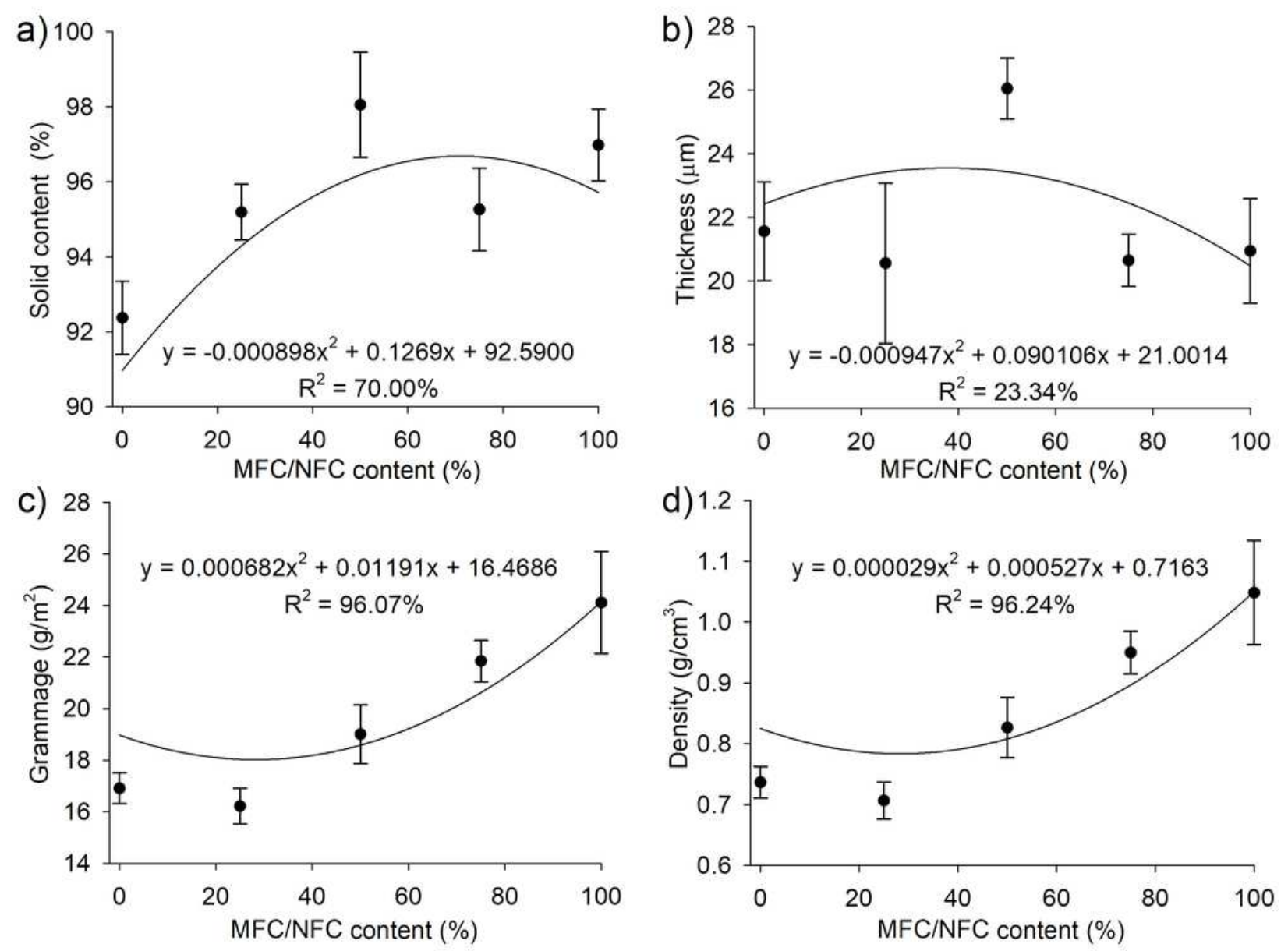

\section{Figure 2}

Regression models for a) solids content, b) thickness, c) grammage and d) density of HPMC films reinforced with different MFC/NFC contents 


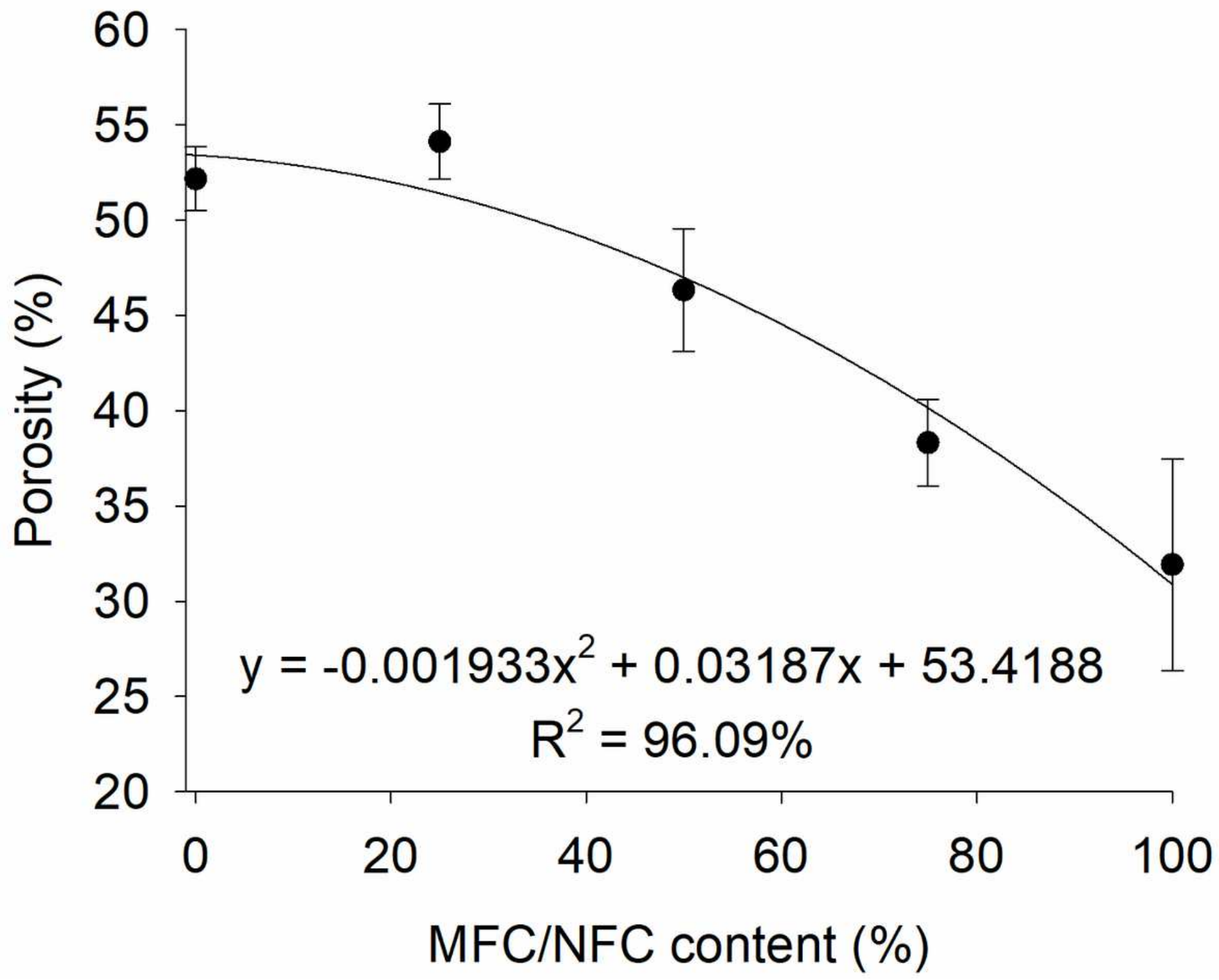

Figure 3

Regression models for porosity of HPMC films reinforced with different MFC/NFC contents 


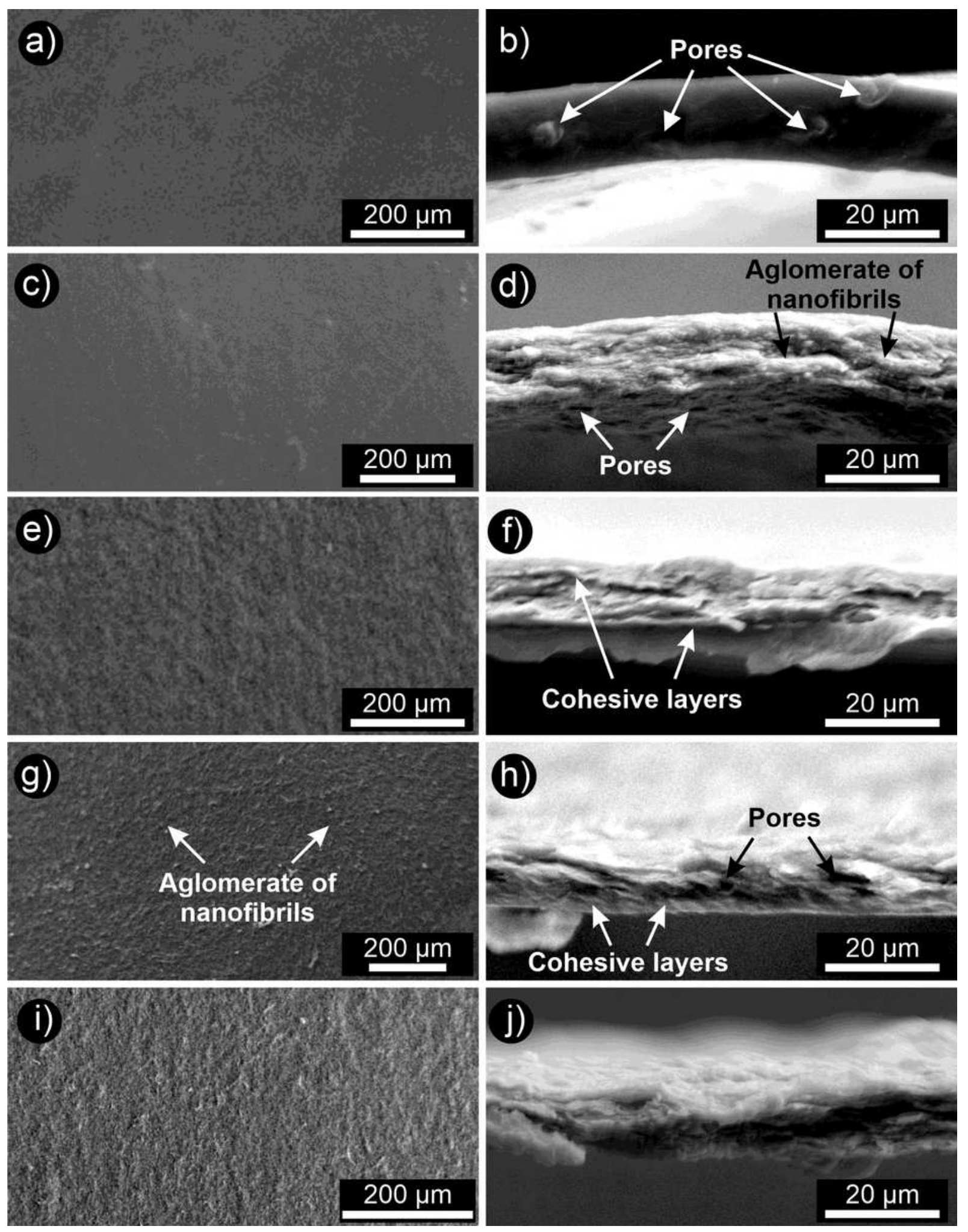

Figure 4

SEM micrographs of HPMC films reinforced with different contents of MFC/NFC; a) $100 \%$ HPMC- surface; b) $100 \%$ HPMC - cross section; c) $25 \%$ MFC/NFC - surface; d) $25 \%$ MFC/NFC - cross section; e) $50 \%$ MFC/NFC - surface; f) $50 \%$ MFC/NFC - cross section; g) 75\% MFC/NFC - surface; h) 75\% MFC/NFC - cross section; i) 100\% MFC/NFC - surface; j) $100 \%$ MFC/NFC - cross section 


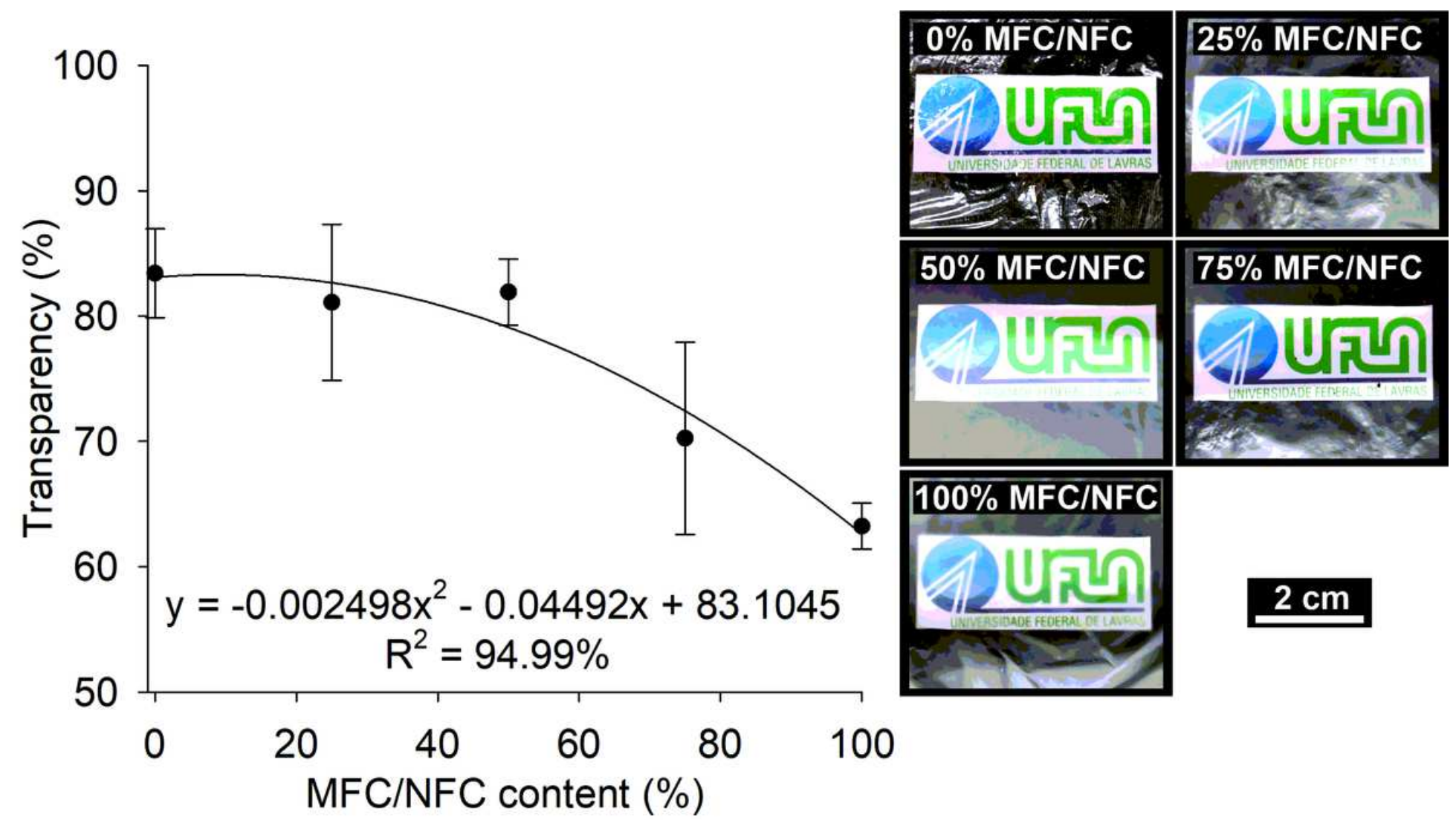

Figure 5

Transparency of HPMC films reinforced with different MFC/NFC contents
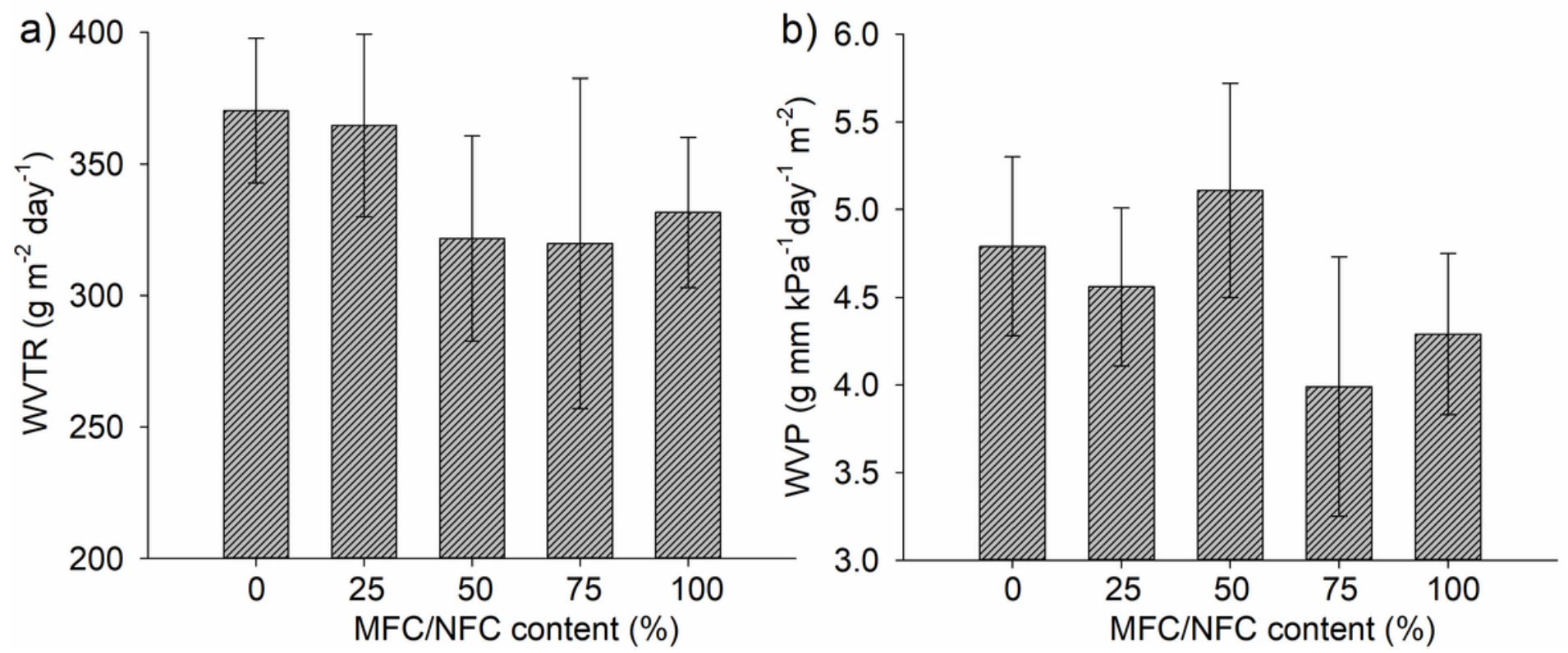
Figure 6

Water vapor transmission rate (WVTR) and water vapor permeability (WVP) of HPMC films reinforced with different MFC/NFC contents

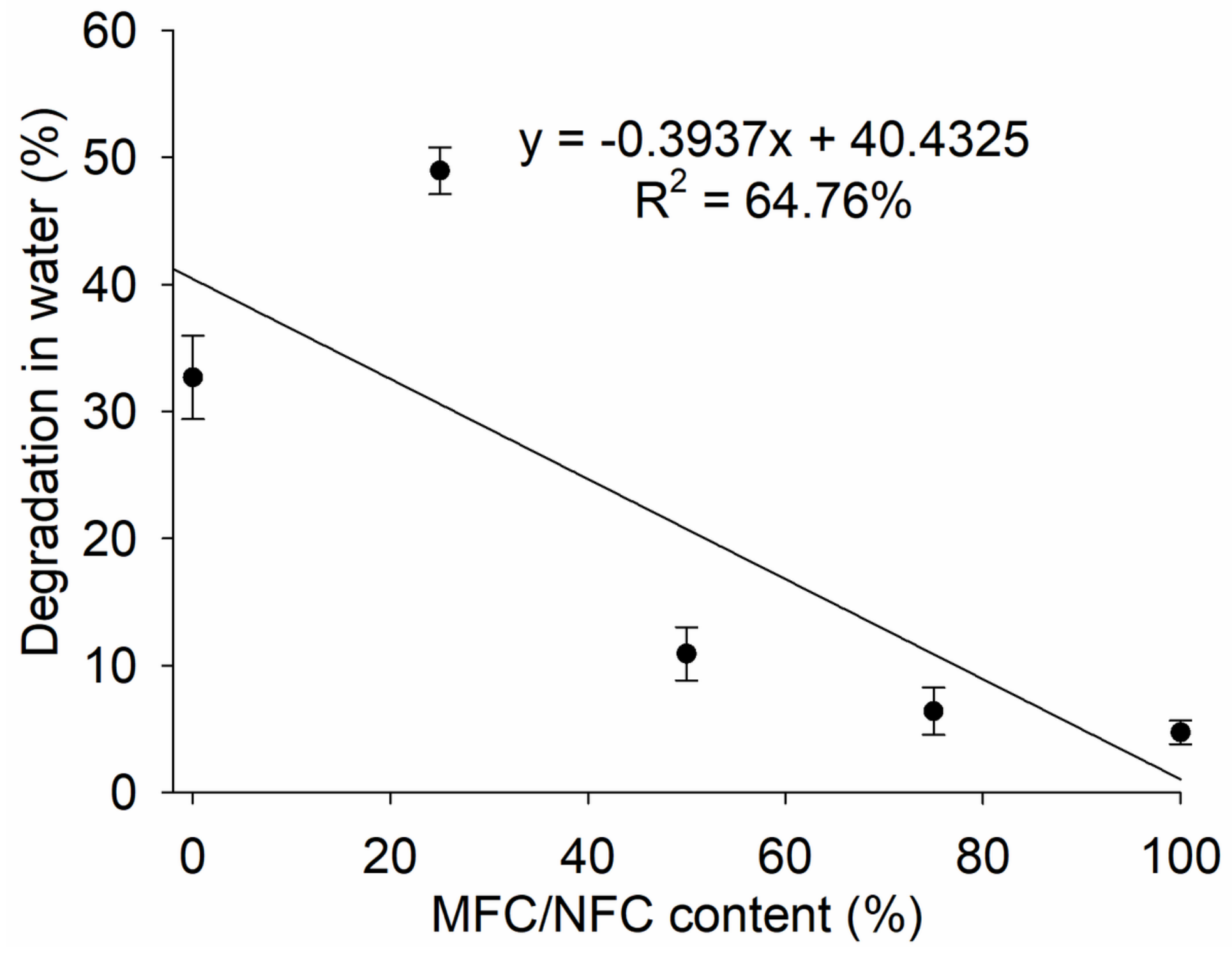

Figure 7

Regression model for degradation in water of HPMC films reinforced with different MFC/NFC contents 

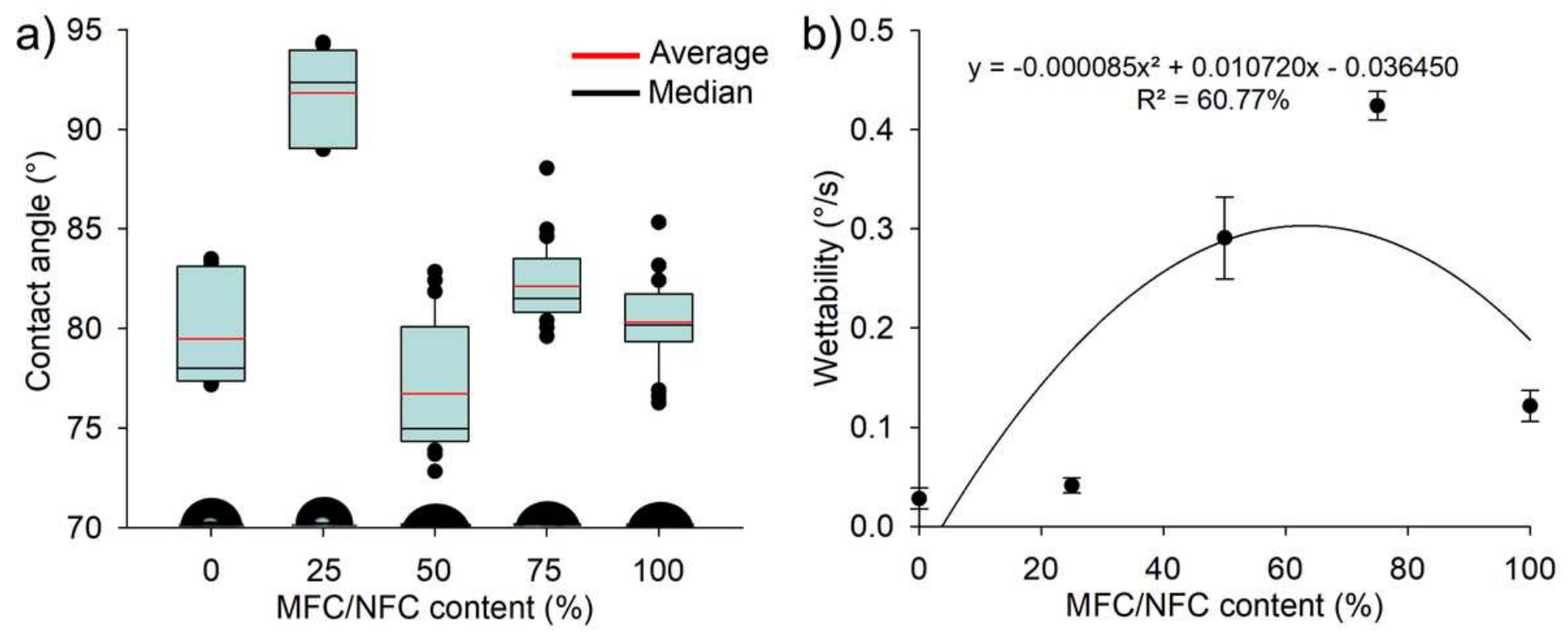

Figure 8

a) Contact angle and b) regression model for wettability of HPMC films reinforced with different MFC/NFC contents 

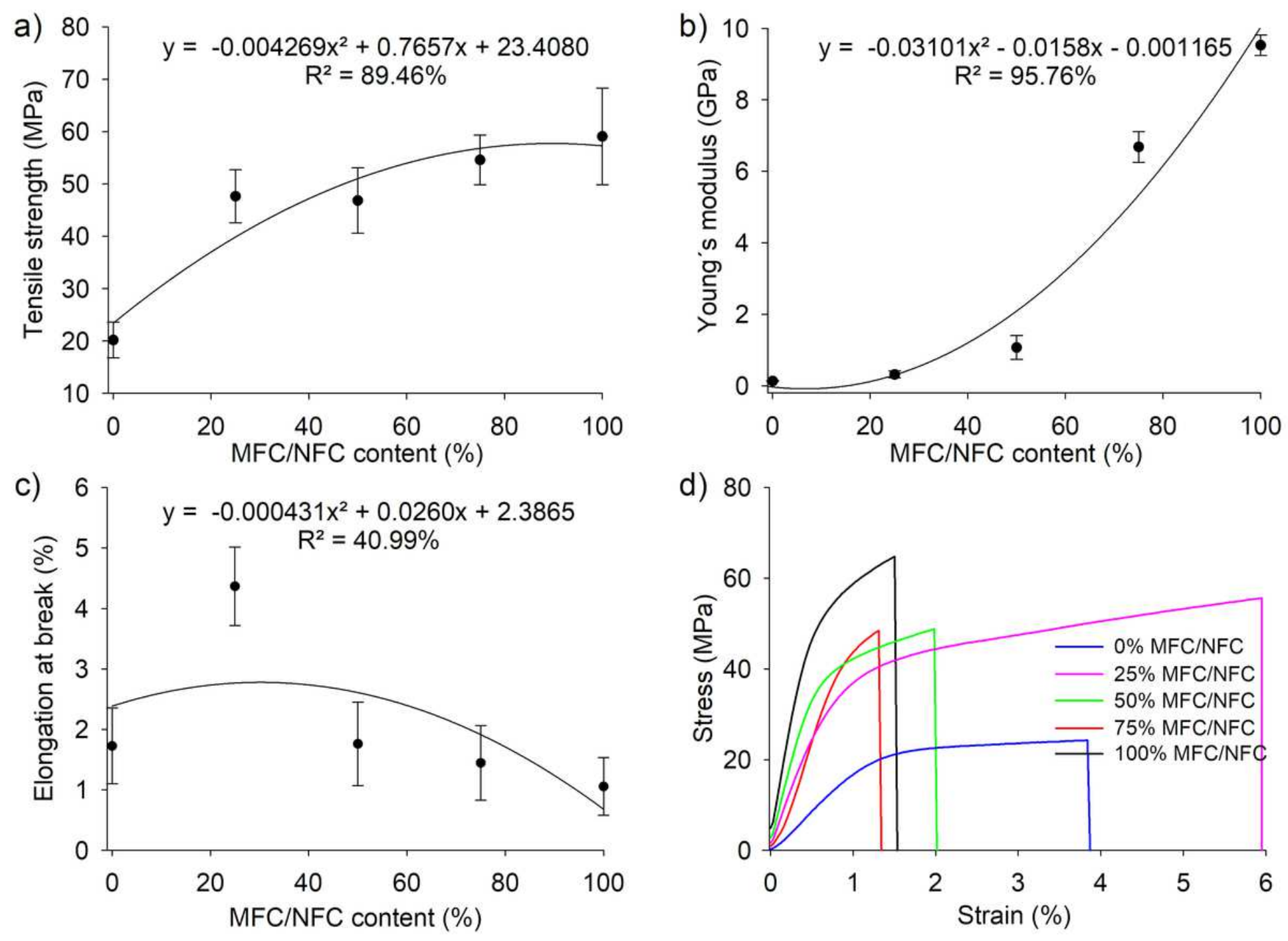

Figure 9

Regression models for a) tensile strength, b) Young's Modulus, c) elongation at break and d) characteristic curves for tensile test of HPMC films reinforced with different MFC/NFC contents 


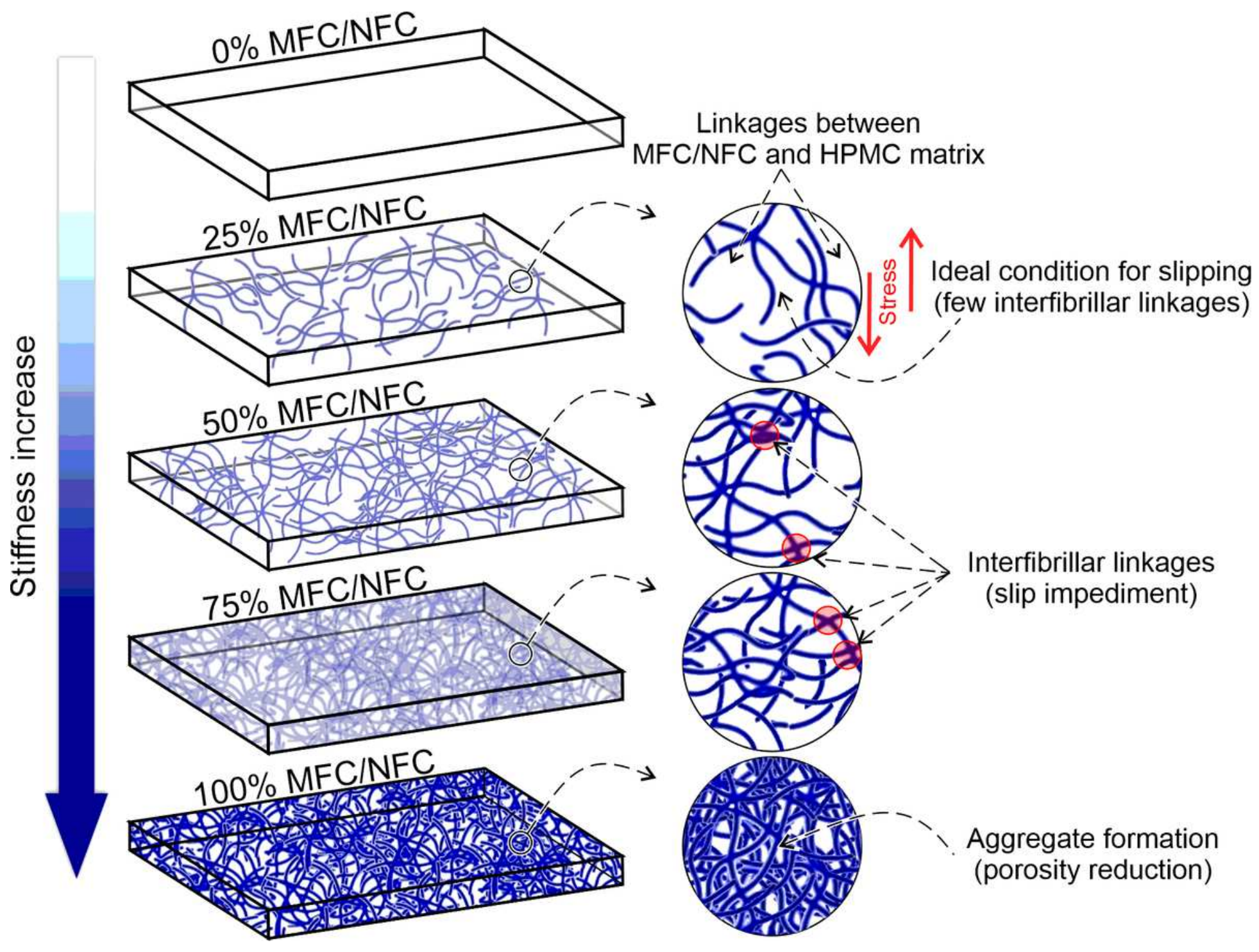

Figure 10

Scheme showing the increase of film stiffness and reduction of slippage with greater amounts of MFC/NFC in the HPMC matrix 


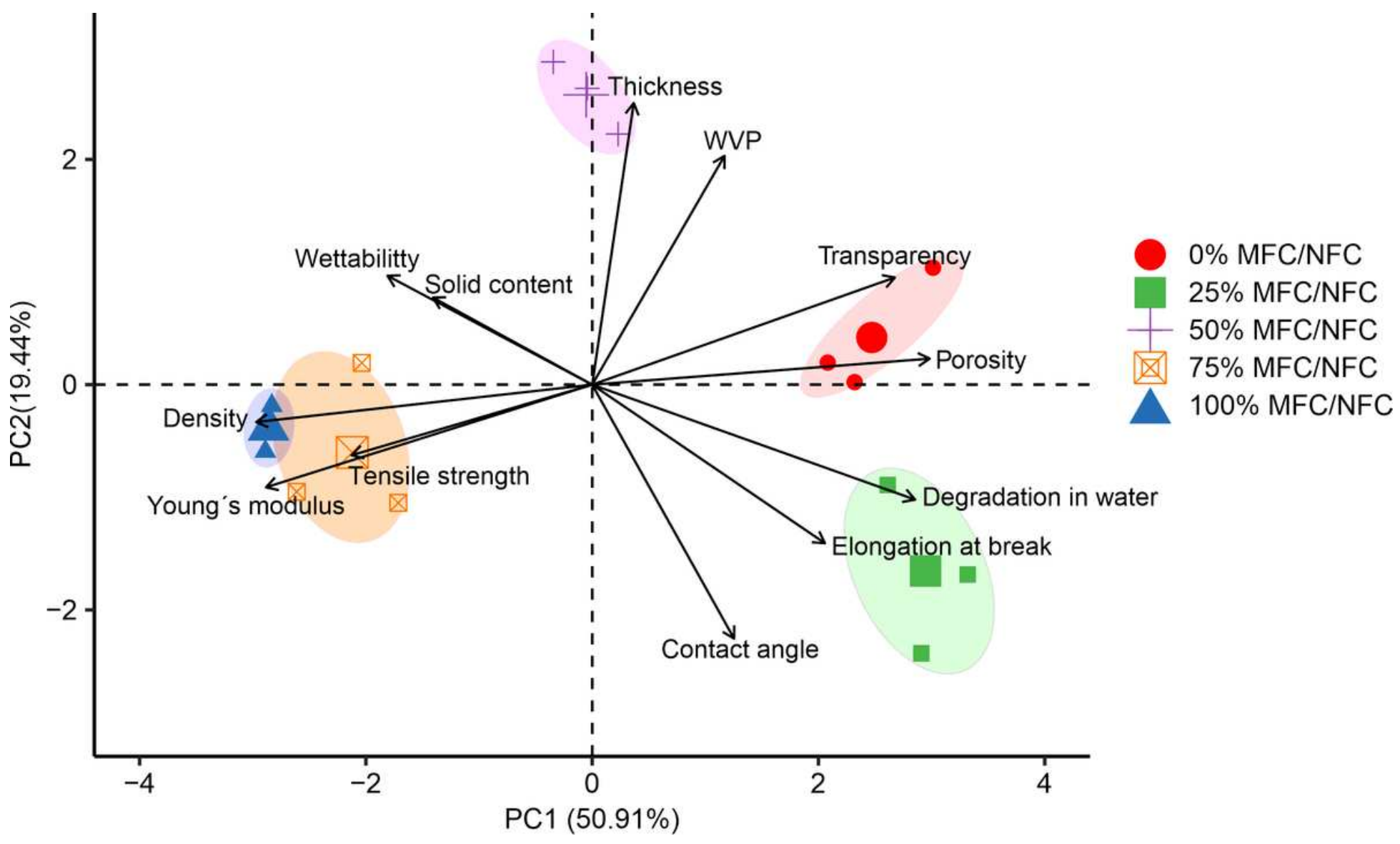

Figure 11

Principal Component Analysis (PCA) for physical, optical, barrier and mechanical properties, and grouping of HPMC films reinforced with different MFC/NFC contents 


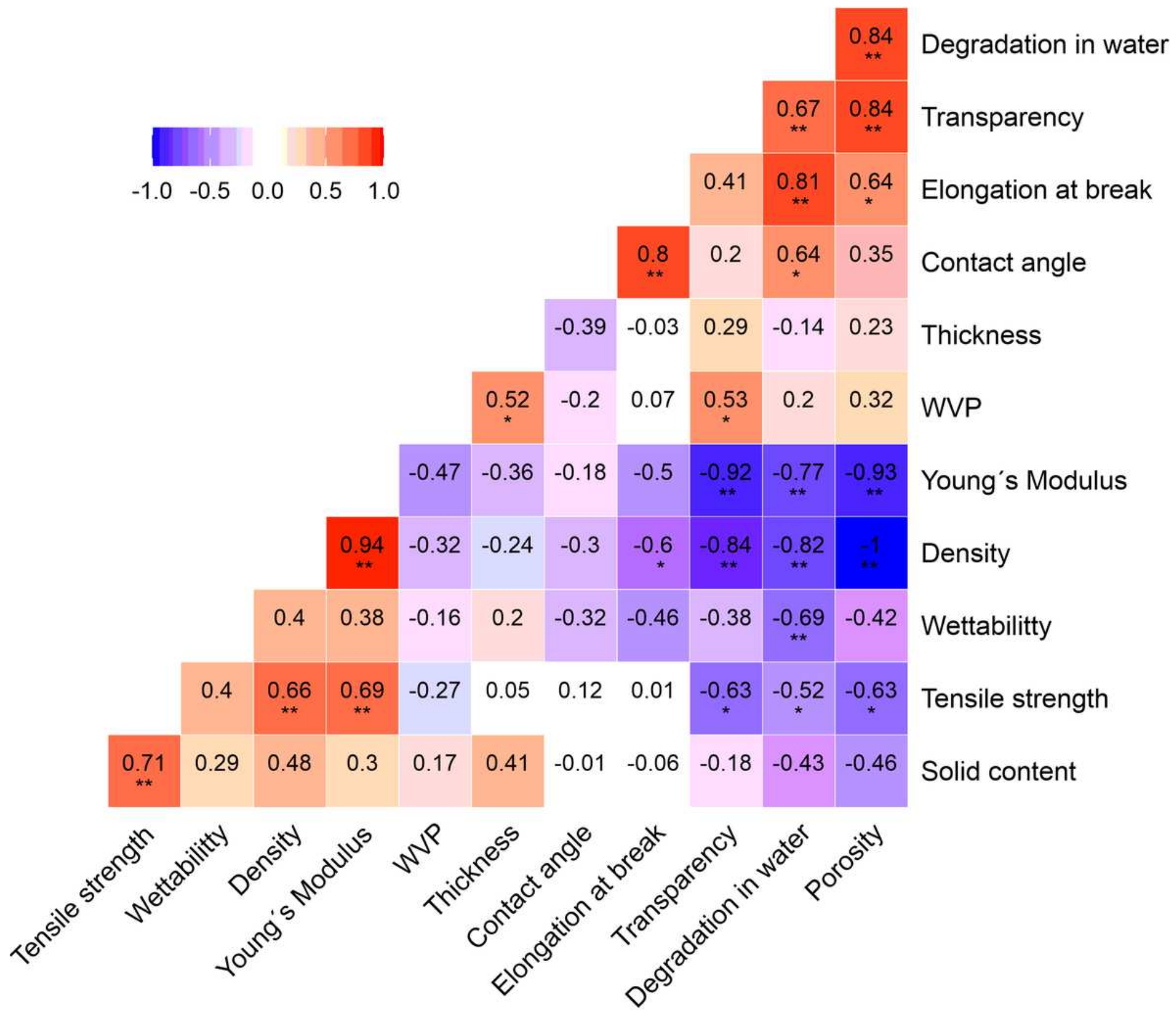

Figure 12

Correlogram for Pearson correlation between physical, optical, barrier and mechanical properties of HPMC films reinforced with different MFC/NFC contents 